\title{
The on-road exhaust emissions characteristics of SUV vehicles fitted with diesel engines
}

\begin{abstract}
The paper presents the results of on-road exhaust emission tests of Sport Utility Vehicles fitted with diesel engines, and a DPF (diesel particulate filter). Under such conditions the authors could determine the actual vehicle emissions. The tests were performed on a road portion of a hundred kilometers or so - these tests provide information on the on-road emissions and are a basis for their ecological evaluation. For the measurement of the exhaust emissions the authors used a portable exhaust emissions analyzer SEMTECH DS by Sensors Inc. The analyzer measured the concentration of the exhaust components at the same time measuring the exhaust mass flow. The measurements of the particulate matter (mass, number and spectral distribution) were done with the use of particle analyzer by AVL and a mass spectrometer by TSI. The obtained data were used to calculate the relations that characterize the influence of the dynamic engine parameters on the exhaust emissions. These properties were taken into account indirectly using the whole range of speeds and accelerations of the vehicle for the preparation of the matrices of the emissions rate. The used data were averaged within individual speed and acceleration ranges thus obtaining the characteristics of the share of operation in individual ranges and the characteristics of the emission matrices of the individual emission components. The above results served for defining of the emission level indicator of the vehicles that can be used for classification of vehicle fleet in terms of their emission level.
\end{abstract}

Key words: on-road tests, exhaust emissions, ecology

\section{Charakterystyka emisyjności pojazdów kategorii SUV z silnikami ZS w rzeczywistych warunkach ruchu}

\begin{abstract}
W artykule przedstawiono wyniki badań emisyjnych samochodów kategorii SUV (Sport Utility Vehicle) z silnikami $Z S$, wyposażonych $w$ filtr cząstek statych $w$ warunkach drogowych $-w$ takich warunkach można uzyskać informację o rzeczywistej ich emisji. Testy wykonywano na odcinku stu kilkudziesięciu kilometrów podczas rzeczywistych warunków jazdy - zawieraja one informację o eksploatacyjnej emisyjności pojazdów i sa podstawa do ekologicznej ich oceny. Do pomiarów stężenia związków toksycznych wykorzystano mobilny analizator do badań toksyczności SEMTECH DS firmy Sensors Inc. Analizator umożliwiat pomiar stężenia związków szkodliwych, mierząc jednocześnie masowe natężenie spalin. Pomiary emisji czastek statych (masy, liczby i rozkładu widmowego) wykonano z wykorzystaniem analizatora czastek stałych firmy AVL oraz spektrometru masowego firmy TSI. Uzyskane dane postużyly do opracowania zależności, które charakteryzuja wpływ dynamicznych właściwości silnika na emisję związków szkodliwych. Właściwości te uwzględniono w sposób pośredni, wykorzystując przedziat catego zakresu prędkości oraz zakresu przyspieszenia pojazdu do wykonania macierzy natężenia emisji. Wykorzystane dane uśredniono w ramach poszczególnych przedziatów prędkości i przyspieszenia, otrzymując charakterystykę udziału pracy pojazdu w poszczególnych przedziałach oraz charakterystyki macierzy emisji poszczególnych związków szkodliwych. Powyższe wyniki posłużyły do zdefiniowania wskaźnika emisyjności pojazdów, który można wykorzystać do klasyfikacji flot pojazdów pod względem emisji związków toksycznych.

Słowa kluczowe: badania drogowe, emisja spalin, ekologiczność pojazdów
\end{abstract}

\section{Introduction}

Currently a trend has been seen of global treatment of the environmental perils from the automotive industry. The regulations permitting the vehicle to drive on roads (homologations and production conformity), periodical inspections of the vehicle technical condition and other legal acts directly or indirectly related to the production, use and disposal of used up civilization products treat the environmental issues in a complex way. In the previous years in individual countries there were different inspection and testing systems related to the exhaust emissions yet for some time now there has been a far reaching unification going on $[3,7,9]$.

The growing number of vehicles in the world and the resultant natural environment pollution leads to a growth

\section{Wprowadzenie}

Obecnie zauważa się tendencję do globalnego traktowania zagrożeń środowiska ze strony motoryzacji. Przepisy zezwalające na dopuszczenie pojazdów do użytkowania (badania homologacyjne i zgodności produkcji), okresowe badania kontroli stanu technicznego oraz pozostałe akty prawne związane bezpośrednio i pośrednio z produkcją, użytkowaniem i zagospodarowaniem zużytych wytworów cywilizacji, traktują zagadnienia ochrony środowiska $\mathrm{w}$ sposób kompleksowy. Na przestrzeni minionych lat w poszczególnych państwach istniały różne systemy badań i kontroli emisji spalin z silników samochodowych, jednak od pewnego czasu następuje w tym zakresie daleko posunięta unifikacja $[3,7,9]$. 
in the emission related requirements. Current level of technology advancement in all the fields of industry including transport results in a growth of the requirements for the emission measurement devices. In order for these requirements to be fulfilled to comply with the ever-changing regulations a concentration of industry became necessary in this matter. The exhaust emission tests are a sophisticated process. Modern analyzers of the emissions require special laboratory conditions and the homologation procedures comprise tests on chassis and engine dynamometers that do not entirely reflect the emissions under real operating conditions. The latest results of on-road tests show that in relation to some exhaust components the emission is higher by several hundred percent for both the gaseous compounds and [1-5, 15] particulate matter $[6,8,10,11]$. Hence, we can see a trend attempting at a formalization and enforcement of the on-road emission testing.

\section{Methodology of research}

The aim of the tests was a verification of the emission level of vehicles in the category of SUV (Sport Utility Vehicle) fitted with diesel engines, Euro 4/Euro 5 compliant under real traffic conditions. At the same time the tests were an attempt to develop an on-board exhaust emission measurement system. The determining of the on-road emission level and comparing it with the standards allowed a determination of the emission indicator. The obtained emission indicator served as an answer to the question whether the emissions under traffic conditions are comparable to the emissions obtained in the homologation tests. At the same time it is a verification of the conditions of the performance of the homologation test and the real traffic conditions.

The measurement of the on-road exhaust emission was performed under real traffic conditions: urban drive (share in the whole test $-13 \%)$, extra urban (42\%), freeway (45\%) in the province of Wielkopolska (Fig. 1). The route profile differed in terms of elevation above the sea level and the maximum difference was 55 meters. Two vehicles were tested for which the drives were repeated three times. The differences in the values in the subsequent trials did not exceed $5 \%$ of the average value. The tests consisted in the measurement of the exhaust components $\left(\mathrm{CO}, \mathrm{HC}, \mathrm{NO}_{\mathrm{x}}\right.$ and particulate matter for each vehicle) and then with the use of the GPS and OBD data the road emission of each exhaust component was determined.

The object of the investigations were vehicles (Fig. 2) whose drivetrain characteristics has been presented in Table 1 . They are characterized with different emission standards, which resulted from the use of a DPF filter or its lack. Despite difference in the curb weight and engine capacity the common feature of the selected vehicles was the value of the volumetric power output indicator that amounted to approximately $50 \mathrm{~kW} / \mathrm{dm}^{3}$.
Rosnąca liczba pojazdów na świecie i związane z tym zanieczyszczenie środowiska naturalnego powodują wzrost wymagań w zakresie emisji szkodliwych składników spalin. Obecny stopień zaawansowania techniki i technologii we wszystkich dziedzinach przemysłu, w tym również we wszelkich rodzajach transportu, powoduje wzrost wymagań odnośnie do produkcji urządzeń do pomiarów emisji spalin. Aby te wymagania mogły być spełniane w stopniu koniecznym do zmieniających się okresowo przepisów, konieczna stała się koncentracja przemysłu w tej dziedzinie. Badania emisji toksycznych składników spalin są procesem skomplikowanym. Obecne analizatory do pomiaru emisji wymagają szczególnych warunków laboratoryjnych, a procedury homologacyjne obejmują testy na hamowniach silnikowych i podwoziowych, które jednak nie odzwierciedlają emisji w rzeczywistych warunkach eksploatacji. Najnowsze wyniki badań prowadzonych w warunkach rzeczywistych ukazują, że w odniesieniu do niektórych składników toksycznych spalin emisja ta jest większa o kilkaset procent zarówno związków gazowych [1-5, 15], jak i cząstek stałych [6, 8, $10,11]$. W związku z powyższym dostrzegalny jest trend usankcjonowania pomiaru emisji w warunkach rzeczywistej eksploatacji pojazdów.

\section{Metodyka badań}

Celem badań była weryfikacja emisyjności pojazdów kategorii SUV (Sport Utility Vehicle) z silnikami ZS, spełniających normę Euro 4/Euro 5, podczas rzeczywistych warunków ruchu drogowego. Jednocześnie badania były próbą stworzenia pokładowego systemu pomiarowego związków szkodliwych. Wyznaczenie emisyjności w warunkach drogowych i porównanie jej z wartościami normatywnymi, pozwoliło na określenie wskaźnika emisyjności. Wyznaczony wskaźnik emisyjności posłużył do odpowiedzi na pytanie: czy emisja w warunkach drogowych jest porównywalna $\mathrm{z}$ emisją uzyskiwaną podczas testu homologacyjnego. Jednocześnie jest to weryfikacja warunków wykonywania testu homologacyjnego i warunków rzeczywistych ruchu pojazdów.

Pomiarów emisyjności w warunkach drogowych dokonano w rzeczywistych warunkach ruchu: jazda miejska (udział w całości testu - 13\%), pozamiejska (42\%), autostradowa (45\%) na terenie województwa wielkopolskiego (rys. 1). Profil drogi był zróżnicowany pod względem wysokości 
A
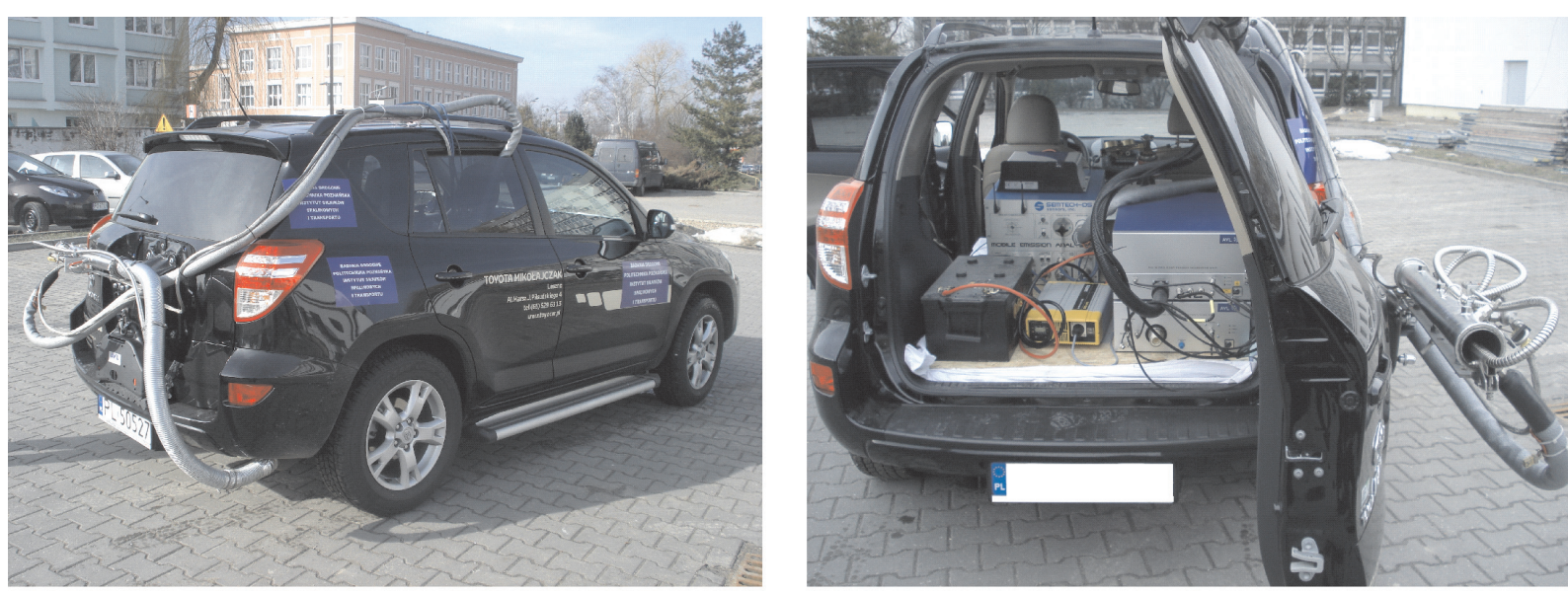

B
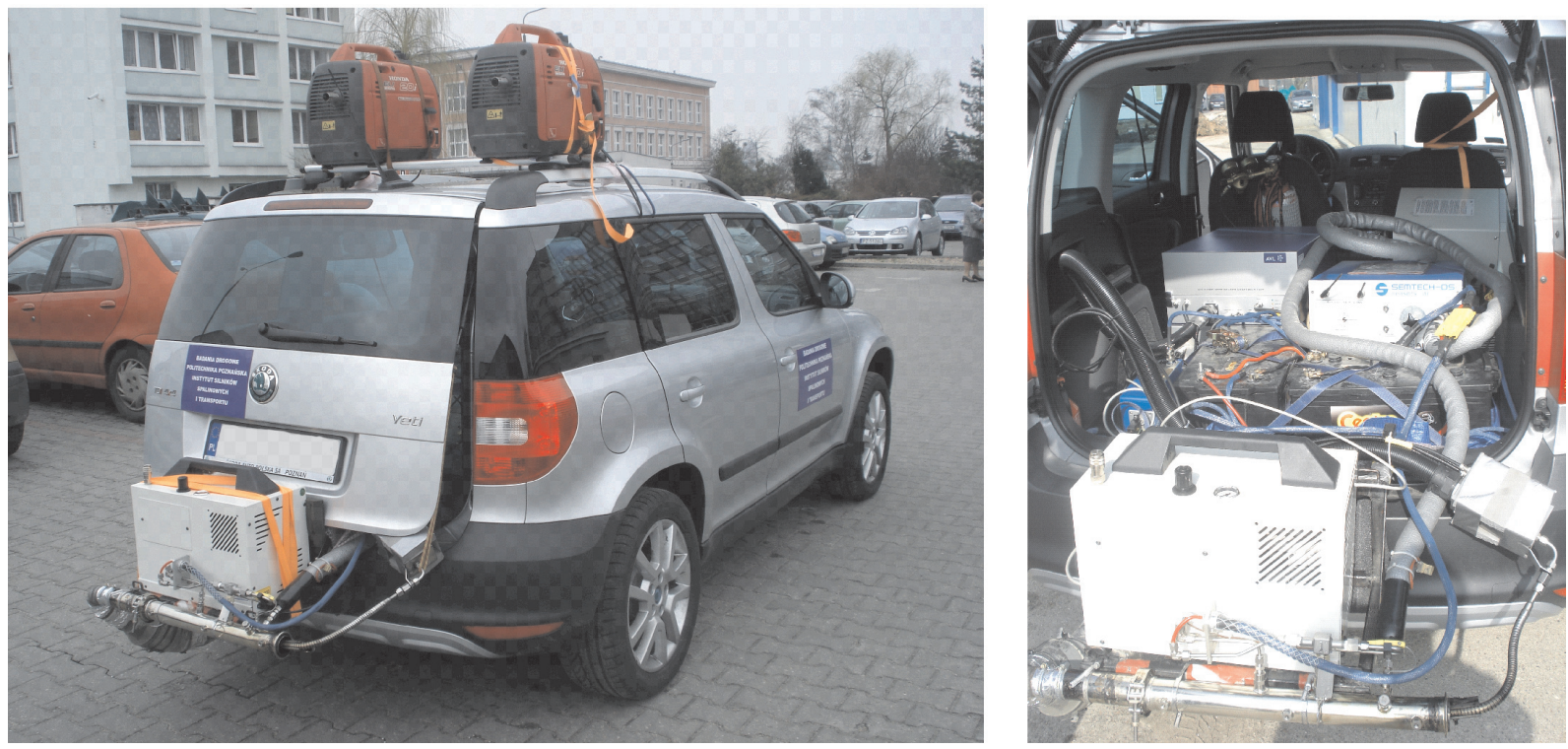

Fig. 2. Exhaust emission analyzers fitted in vehicles $A$ and $B$ during the tests

Rys. 2. Analizatory spalin zamontowane w pojazdach A i B podczas badań

Table 1. Technical specifications of the vehicles used in the tests

Tabela 1. Charakterystyka pojazdów wykorzystanych w badaniach

\begin{tabular}{|l|c|c|c|}
\hline Parameters/parametry obiektów & Unit/jednostka & Vehicle A/pojazd A & Vehicle B/pojazd B \\
\hline $\begin{array}{l}\text { Type of engine/aspiration/rodzaj silnika/ } \\
\text { zasilania }\end{array}$ & - & $\begin{array}{c}\text { Diesel/turbocharged/ } \\
\text { ZS/dotadowany }\end{array}$ & $\begin{array}{c}\text { Diesel/turbocharged/ } \\
\text { ZS/ doładowany }\end{array}$ \\
\hline Capacity/pojemność silnika & $\mathrm{dm}^{3}$ & 2.2 & 2.0 \\
\hline Number of cylinders/liczba cylindrów & - & 4 & $103 / 4200$ \\
\hline Power output/moc & $\mathrm{kW} /(\mathrm{rpm})$ & $110 / 3600$ & $320 / 1750-2500$ \\
\hline Torque/moment obrotowy & $\mathrm{N} \cdot \mathrm{m} /(\mathrm{rpm})$ & $340 / 2000-2800$ & 51.5 \\
\hline $\begin{array}{l}\text { Volumetric power output indicator/ } \\
\text { objętościowy wskaźnik mocy }\end{array}$ & $\mathrm{kW} / \mathrm{dm}^{3}$ & 50 & 1550 \\
\hline Vehicle curb weight/masa wlasna pojazdu & $\mathrm{kg}$ & 1590 & $\begin{array}{c}\text { oxycat, DPF /Euro 5/reaktor utleniaja- } \\
\text { cy, filtr czastek stalych/Euro 5 }\end{array}$ \\
\hline $\begin{array}{l}\text { Aftertreatment/Euro standard/system oczysz- } \\
\text { czania spalin/norma spalin }\end{array}$ & - & $\begin{array}{c}\text { oxycat/Euro 4/ } \\
\text { reaktor utleniajacy/Euro 4 }\end{array}$ & 2000 \\
\hline Vehicle mileage/przebieg pojazdu & 15 000 & EOBD/CAN 2.0/b \\
\hline Diagnostic system/system diagnostyczny & & EOBD/CAN 2.0/b & \\
\hline
\end{tabular}

For the measurement of the exhaust emissions the authors used a portable exhaust emissions analyzer SEMTECH DS by Sensors Inc. (tab. 2). The analyzer enables a meas- n.p.m., a maksymalna różnica wynosiła $55 \mathrm{~m}$. Badania dotyczyły dwóch pojazdów, dla których przejazdy powtarzano trzykrotnie. Różnice wartości w kolejnych próbach 
urement of the concentration s of the exhaust components $\left(\mathrm{CO}, \mathrm{HC}, \mathrm{NO}_{\mathrm{x}}, \mathrm{CO}_{2}\right.$ ) and a mass flow of the exhaust gases. The exhaust gases introduced into the analyzer through a measuring probe maintaining the temperature of $191{ }^{\circ} \mathrm{C}$ are filtered out of the particulate matter (diesel engines only) and directed to the flame ionization detector where the measurement of hydrocarbons takes place. The exhaust gases are cooled down to the temperature of $4{ }^{\circ} \mathrm{C}$ and the concentration of nitric oxides is measured (non-dispersive ultraviolet-measuring both nitrogen monoxide and nitrogen dioxide). At the end the concentration of carbon monoxide and carbon dioxide (non-dispersive infrared method) and oxygen (electrochemical) are measured. The data from the GPS and OBD can be fed directly to the central unit of the analyzer.

In the tests the authors measured the exhaust emissions and also, for comparison, recorded data from the on-board diagnostics such as engine speed, engine load and vehicle speed. Some of these signals served for the determination of the time density map of the engine share of operation under traffic conditions. The GPS signal; was used for the visualization of the obtained data.

For the measurement of particulate matter the authors used a portable analyzer by AVL 483 (Micro Soot Sensor) that enables a continuous measurement of PM in diluted exhaust gases. The principle of operation of this device uses a photoacoustic method that allows a measurement of PM starting from the value of $5 \mu \mathrm{g} / \mathrm{m}^{3}$. The measurement of PM (the device measures the carbon part of the particle) with the photoacoustic method consists in a significant absorption of the laser light by the soot particles. This results in a periodical (interchanging) heating and cooling of the working gas (change in the pressure in the measurement chamber) and the generated sound wave is recorded by the microphones. The basic technical specifications of the analyzer have been shown in Table 3. nie przekraczały 5\% wartości średniej. Badania polegały na pomiarze stężenia związków szkodliwych $\left(\mathrm{CO}, \mathrm{HC}, \mathrm{NO}_{\mathrm{x}}\right.$ oraz cząstek stałych dla każdego pojazdu), a następnie $\mathrm{z}$ wykorzystaniem danych z systemu lokalizacji pojazdu GPS oraz systemu diagnostycznego określono emisję drogowa każdego związku.

Obiektem badań były pojazdy (rys. 2), których charakterystykę jednostek napędowych przedstawiono w tab. 1. Charakteryzowały się one spełnieniem różnych norm toksyczności spalin, co wynikało m.in. z zastosowania filtra cząstek stałych lub jego braku. Pomimo różnic w masach własnych pojazdów i pojemności silników, cechą wspólną tak wybranych pojazdów była wartość objętościowego wskaźnika mocy, który dla wybranych pojazdów wynosił ok. $50 \mathrm{~kW} / \mathrm{dm}_{3}$.

Do pomiarów stężenia związków toksycznych wykorzystano mobilny analizator do badań toksyczności SEMTECH DS firmy Sensors Inc. (tab. 2). Analizator umożliwiał pomiar stężenia związków szkodliwych $\left(\mathrm{CO}, \mathrm{HC}, \mathrm{NO}_{x}\right.$, $\mathrm{CO}_{2}$ ) oraz jednocześnie masowego natężenia przepływu spalin. Gazy spalinowe wprowadzane do analizatora za pomocą sondy pomiarowej utrzymującej temperaturę $191{ }^{\circ} \mathrm{C}$ są filtrowane z cząstek stałych (dla silników ZS) i kierowane do analizatora płomieniowo-jonizacyjnego, w którym następuje pomiar stężenia węglowodorów. Następnie spaliny są schładzane do temperatury $4{ }^{\circ} \mathrm{C}$ i wykonywany jest pomiar stężenia tlenków azotu (metodą niedyspersyjną z wykorzystaniem promieniowania ultrafioletowego, umożliwiającą jednoczesny pomiar tlenku azotu i dwutlenku azotu). Na końcu następuje pomiar stężenia tlenku węgla i dwutlenku węgla (metodą niedyspersyjną z wykorzystaniem promieniowania podczerwonego) oraz tlenu (analizatorem elektrochemicznym). Do jednostki centralnej analizatora można doprowadzić dane przesyłane bezpośrednio z systemu diagnostycznego pojazdu oraz wykorzystać sygnał lokalizacji GPS.

Table 2. Technical specifications of the portable exhaust emission analyzer - SEMTECH DS [11]

Tabela 2. Charakterystyka mobilnego analizatora spalin SEMTECH DS [11]

\begin{tabular}{|c|c|c|}
\hline Parameter/parametr & Measurement method/metoda pomiaru & Accuracy/doktadność \\
\hline $\begin{array}{l}\text { 1. Exhaust component concen- } \\
\text { tration/stężenie zwiąków } w \\
\text { spalinach } \\
\mathrm{CO} \\
\mathrm{HC} \\
\mathrm{NO}_{x}=\left(\mathrm{NO}+\mathrm{NO}_{2}\right) \\
\mathrm{CO}_{2} \\
\mathrm{O}_{2}\end{array}$ & $\begin{array}{l}\text { NDIR analyzer/analizator, measurement range/zakres } \\
\text { pomiarowy } 0-10 \% \\
\text { FID analyzer/analizator, range/zakres } 0-10000 \mathrm{ppm} \\
\text { NDUV analyzer/analizator, range/zakres } 0-3000 \mathrm{ppm} \\
\text { NDIR analyzer/analizator, range/zakres } 0-20 \% \\
\text { Electrochemical analyzer/analizator elektrochemiczny, } \\
\text { range/zakres } 0-20 \%\end{array}$ & $\begin{array}{l} \pm 3 \% \text { of the measurement range/zakresu pomiaru } \\
\pm 2 \% \text { of the measurement range/zakresu pomiaru } \\
\pm 3 \% \text { of the measurement range/zakresu pomiaru } \\
\pm 3 \% \text { of the measurement range/zakresu pomiaru } \\
\pm 1 \% \text { of the measurement range/zakresu pomiaru }\end{array}$ \\
\hline $\begin{array}{l}\text { 2. Exhaust gas flow/przeplyw } \\
\text { spalin }\end{array}$ & $\begin{array}{l}\text { Mass flow rate/masowe natężenie przeptywu } \\
\qquad \mathrm{T}_{\max } \text { do } 700{ }^{\circ} \mathrm{C}\end{array}$ & $\begin{array}{c} \pm 2.5 \% \text { range } / \text { zakres } \\
\pm 1 \% \text { range } / \text { zakres }\end{array}$ \\
\hline $\begin{array}{l}\text { 3. Warm up time/czas nagrze- } \\
\text { wania }\end{array}$ & $900 \mathrm{~s}$ & - \\
\hline $\begin{array}{l}\text { 4. Response time/czas } \\
\text { odpowiedzi }\end{array}$ & $\mathrm{T}_{90}<1 \mathrm{~s}$ & - \\
\hline $\begin{array}{l}\text { 5. Supported diagnostic } \\
\text { systems/obstugiwane systemy } \\
\text { diagnostyczne }\end{array}$ & $\begin{array}{l}\text { SAE J1850/SAE J1979/SAE } 15765 \\
\text { OBD: ISO, CAN, VPW, PWM }\end{array}$ & - \\
\hline
\end{tabular}


For the measurement of the particle size distribution (as a dependence of their diameter) a mass spectrometer by TSI Incorporated - 3090 EEPS (Engine Exhaust Particle Sizer ${ }^{\mathrm{TM}}$ Spectrometer) was used, whose parameters have been shown in table 4 . The analyzer continuously measures the distribution of the PM size. It also measures the discrete range of particle diameter (from 5.6 to $560 \mathrm{~nm}$ ) based on their different velocities. The range of the electrical motility of the particles changes exponentially and the measurement of the PM takes place with the frequency of $10 \mathrm{~Hz}$.

The diluted exhaust gases of proper temperature were directed to the particle counter and mass spectrometer. Hence, the overall number of particles and the qualitative and quantitative distribution were given in each size range.

Table 3. Technical specifications of the PM analyzer AVL MSS 438 [13] Tabela 3. Dane techniczne analizatora czastek stalych AVL MSS 438 [13]

\begin{tabular}{|l|c|}
\hline Parameter/parametr & Value/wartość \\
\hline Measurement range/zakres pomiaru & $0 \div 50 \mathrm{mg} / \mathrm{m}^{3}$ \\
\hline Resolution/rozdzielczość & $0.001 \mathrm{mg} / \mathrm{m}^{3}$ \\
\hline Dilution rate/stopień rozciénczenia & 5000 \\
\hline Sample uptake/pobór próbki spalin & $2 \mathrm{dm}^{3} / \mathrm{min}$ \\
\hline $\begin{array}{l}\text { Device operating conditions/warunki } \\
\text { pracy urzadzenia }\end{array}$ & $\begin{array}{c}5 \div 45{ }^{\circ} \mathrm{C}, 0 \div 95 \% \\
\text { humidity } / \text { wilgotność }\end{array}$ \\
\hline
\end{tabular}

Table 4. Technical specifications of the mass spectrometer by TSI [14] Tabela 4. Dane techniczne spektrometru masowego firmy TSI [14]

\begin{tabular}{|l|c|}
\hline Parameter/parametr & Value/wartość \\
\hline $\begin{array}{l}\text { Sizes of measured particles/rozmiar } \\
\text { mierzonych cząstek }\end{array}$ & $5.6-560 \mathrm{~nm}$ \\
\hline $\begin{array}{l}\text { Number of measuring channels/liczba } \\
\text { kanałów pomiarowych }\end{array}$ & $\begin{array}{c}16 \text { channels per decade/ } \\
\text { kanatów na dekadę }\end{array}$ \\
\hline Sample flow/przeplyw próbki spalin & $10 \mathrm{dm}^{3} / \mathrm{min}$ \\
\hline Sample temperature/temp. próbki & $10-52{ }^{\circ} \mathrm{C}$ \\
\hline $\begin{array}{l}\text { Device operating temperature/temp. } \\
\text { pracy urzadzenia }\end{array}$ & $0-40{ }^{\circ} \mathrm{C}$ \\
\hline
\end{tabular}

\section{Test conditions}

In order to confirm the similarity of the drives the operating conditions of the vehicles were compared during real traffic operation (Fig. 3). The drives were done on the same route but they were done in different directions. For vehicle A the speed (Fig. 3a) in the individual parts of the test was as follows: urban area $-\mathrm{V}_{\mathrm{av}}=30 \mathrm{~km} / \mathrm{h}$, intercity roads $-\mathrm{V}_{\mathrm{av}}=70 \mathrm{~km} / \mathrm{h}$, expressway $\mathrm{V}_{\mathrm{av}}=115 \mathrm{~km} / \mathrm{h}$. For vehicle $\mathrm{B}$ similar values were recorded (the differences did not exceed $10 \%$ ).

From the comparison of the data presented in Fig. 3 it results that the drives were characterized by high similarity of the dynamic traffic conditions (the ranges of the occurrence of acceleration, steady vehicle speed, vehicle deceleration and coming to a full halt were compared). The results of the comparison shown in table 5 indicate that in both drives (the one without DPF, Euro 4, vehicle A and the one with DPF, Euro 5 marked B) the differences in the parameters are maximum $25 \%$ (the test duration differs by approximately $19 \%$, steady vehicle speed by $24 \%$, acceleration time by $2.5 \%$ ).
W badaniach wykorzystano pomiary emisji związków toksycznych, a także w celach porównawczych rejestrowano sygnały z pokładowego systemu diagnostycznego, m.in. prędkość obrotową silnika, obciążenie oraz prędkość pojazdu. Niektóre z tych sygnałów posłużyły do określenia mapy gęstości czasowej udziału czasu stanu pracy pojazdu w warunkach rzeczywistej eksploatacji. Sygnał lokalizacji GPS wykorzystano do wizualizacji uzyskanych danych.

Do pomiaru masy cząstek stałych wykorzystano mobilny analizator AVL 483 Micro Soot Sensor umożliwiający ciągły pomiar stężenia cząstek stałych w rozcieńczonych spalinach. Zasada działania urządzenia wykorzystuje metodę fotoakustyczna i pozwala na pomiar cząstek stałych już od wartości $5 \mu \mathrm{g} / \mathrm{m}^{3}$. Pomiar cząstek stałych (urządzenie mierzy część węglową cząstki stałej) metodą fotoakustyczną polega na znacznej absorpcji modulowanego światła laserowego przez cząstki sadzy. Skutkuje to okresowym (przemiennym) ogrzewaniem i chłodzeniem gazu nośnego (zmianą ciśnienia w komorze pomiarowej), a powstająca fala dźwiękowa jest rejestrowana przez mikrofony. Podstawowe dane techniczne analizatora przedstawiono tab. 3 .

Do pomiaru rozkładu wielkości cząstek stałych (jako zależności od ich średnicy) wykorzystano spektrometr masowy firmy TSI Incorporated - 3090 EEPS (Engine Exhaust Particle Sizer ${ }^{\mathrm{TM}}$ Spectrometer), którego parametry techniczne zamieszczono w tab. 4. Analizator umożliwiał ciągły pomiar rozkładu wielkości cząstek stałych emitowanych przez silnik badanego pojazdu. Umożliwiał także pomiar dyskretnego zakresu średnic cząstek (od 5,6 do $560 \mathrm{~nm}$ ) na podstawie zróżnicowanej ich prędkości. Zakres elektrycznej ruchliwości cząstek jest zmieniany wykładniczo, a pomiar wielkości cząstek stałych odbywa się z częstotliwością $10 \mathrm{~Hz}$.

Rozcieńczone spaliny o odpowiedniej temperaturze były kierowane jednocześnie do licznika cząstek stałych i do spektrometru masowego. W związku z tym otrzymywano jednocześnie ogólną liczbę cząstek stałych, a także rozkład ilościowy w każdym przedziale wymiarowym.

\section{Warunki testów badawczych}

W celu stwierdzenia podobieństwa przejazdów porównano warunki pracy pojazdów podczas rzeczywistych warunków ruchu (rys. 3). Przejazdy były wykonywane na tej samej trasie, jednakże charakteryzowały się odwrotnym kierunkiem przejazdu. Dla pojazdu A prędkość przejazdu (rys. 3a) w poszczególnych częściach testu była następująca: miasto $-\mathrm{V}_{\mathrm{sr}}=30 \mathrm{~km} / \mathrm{h}$, droga międzymiastowa $-\mathrm{V}_{\mathrm{sr}}=70$ $\mathrm{km} / \mathrm{h}$, autostrada $\mathrm{V}_{\text {sr }}=115 \mathrm{~km} / \mathrm{h}$. Dla pojazdu B zanotowano podobne wartości (różnice nie przekraczały 10\%).

Z porównania danych przedstawionych na rys. 3 wynika, że przejazdy charakteryzowały się dużym podobieństwem warunków dynamicznych ruchu (porównano zakresy występowania przyspieszenia, stałej prędkości jazdy, hamowania pojazdem oraz zatrzymania). Wyniki porównania zamieszczone w tab. 5 wskazują, że w obu przejazdach (zarówno pojazdem bez filtra cząstek stałych, spełniającego normę Euro 4 - dalej oznaczanego jako pojazd A, jak i pojazdem B - z filtrem cząstek stałych, spełniającym normę Euro 5), różnice $\mathrm{w}$ ich parametrach wynoszą maksymalnie do $25 \%$ 


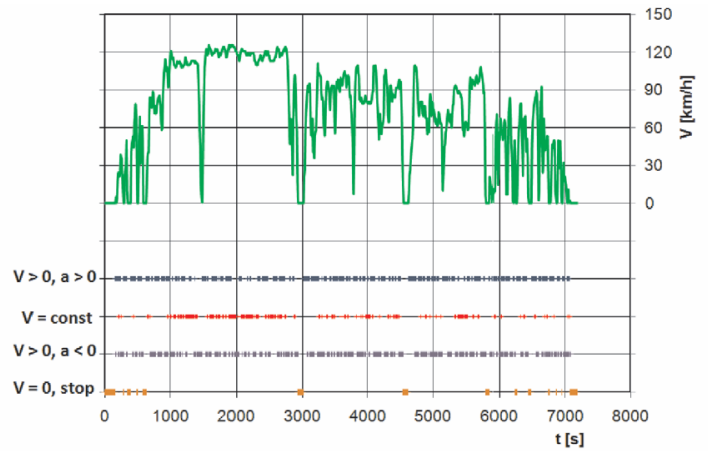

b)

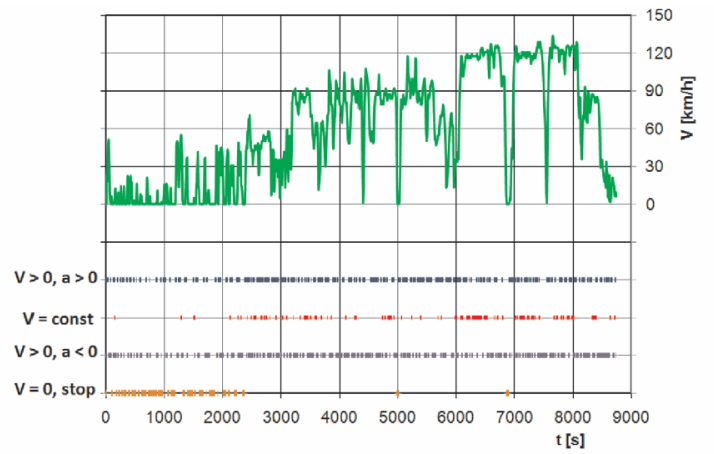

Fig. 3. Vehicle speed during the road tests: a) vehicle A no DPF fitted, emission standard Euro 4, b) vehicle B, DPF fitted, emission standard Euro 5 Rys. 3. Prędkość pojazdów podczas badań drogowych: a) pojazd A bez filtra cząstek stalych, norma emisji spalin Euro 4, b) pojazd B z filtrem czastek stałych, norma emisji spalin Euro 5

The highest difference was recorded for the time when the vehicles were stationary- that amounts to $33 \%$.

It is noteworthy that an on-road test is a type of test where the lack of repeatability is not a disadvantage but a virtue that provides much more information as opposed to stationary tests. When comparing the emissions the authors did not attempt to precisely compare the vehicles but select the parameters for comparison that are objective and do not depend on the repeatability of the tests. Hence, the lack of the repeatability of the tests is characteristic of the real traffic conditions.

\section{Analysis of the test results}

The obtained data served to prepare the relations that characterize the influence of the dynamic engine properties on the exhaust emissions. Dynamic engine properties were indirectly taken into account, using the division of the whole range of speeds and accelerations under real traffic conditions to develop the matrices of emission intensity. The used data were averaged within the individual speed and acceleration

Table 5. The characteristics of the tests (for the vehicle A and B drives)

Tabela 5. Charakterystyka testów badawczych (dla przejazdów pojazdami A i B)

\begin{tabular}{|c|c|c|c|}
\hline $\begin{array}{l}\text { Test parameters/pomiary } \\
\text { testu }\end{array}$ & $\begin{array}{l}\text { Vehicle A/ } \\
\operatorname{pojazd~A}\end{array}$ & $\begin{array}{l}\text { Vehicle } \mathrm{B} / \\
\text { pojazd B }\end{array}$ & $\begin{array}{l}\text { Relative difference/ } \\
\text { różnica względna } \\
\mathrm{k}_{\mathrm{j}}=\frac{\sum_{0}^{\mathrm{t}} \mathrm{E}_{\mathrm{rzecz}, \mathrm{j}}}{\mathrm{E}_{\text {norma } \mathrm{j}}}\end{array}$ \\
\hline $\begin{array}{l}\text { Total time/ } \\
\text { calkowity czas }[\mathrm{s}]\end{array}$ & 7183 & 8733 & -19.5 \\
\hline $\begin{array}{l}\text { Maximum speed/prędkość } \\
\text { maksymalna }[\mathrm{km} / \mathrm{h}]\end{array}$ & 125 & 133 & -6.2 \\
\hline $\begin{array}{l}\text { Average speed/prędkość } \\
\text { średnia }[\mathrm{km} / \mathrm{h}]\end{array}$ & 70.87 & 59.15 & 18.03 \\
\hline Length/dtugość [km] & 142.6 & 143.4 & -0.6 \\
\hline \multicolumn{4}{|l|}{$\begin{array}{l}\text { Share of the vehicle con- } \\
\text { ditions/udziat warunków } \\
\text { pracy pojazdu: }\end{array}$} \\
\hline $\mathrm{V}=0[\%]$ & 9.03 & 12.68 & -33.6 \\
\hline $\mathrm{V}=$ const $[\%]$ & 13.58 & 10.59 & 24.7 \\
\hline $\mathrm{a}>0[\%]$ & 39.58 & 38.62 & 2.5 \\
\hline
\end{tabular}

(czas trwania testu różni się o ok. 19\%, prędkość stała o 24\%, czas przyspieszania o 2,5\%). Największą różnicę zanotowano dla czasu postoju pojazdów - wynosi ona $33 \%$.

Należy zwrócić uwagę, że badania drogowe należą do badań, w których ich niepowtarzalność nie jest wadą, a wartością, która powoduje duży potencjał informacyjny. Porównując emisję, autorzy nie starali się porównywać w sposób dokładny pojazdów, lecz wybrać takie miary do porównania, które są obiektywne i nie zależą od niepowtarzalności testów. W związku z tym niepowtarzalność wyników jest cechą charakterystyczną warunków rzeczywistych użytkowania pojazdów.

\section{Analiza wyników badań}

Uzyskane dane posłużyły do opracowania zależności charakteryzujących wpływ dynamicznych właściwości silnika na emisję związków szkodliwych. Dynamiczne właściwości silnika uwzględniono w sposób pośredni, wykorzystując podział całego zakresu prędkości oraz zakresu przyspieszenia w rzeczywistych warunkach ruchu do wykonania macierzy natężenia emisji. Wykorzystane dane uśredniono w ramach poszczególnych przedziałów prędkości i przyspieszeń, otrzymując charakterystykę udziału pracy silnika w poszczególnych przedziałach oraz charakterystyki macierzy emisji poszczególnych związków szkodliwych. Największy udział pracy silnika w badanych warunkach ruchu przypada w obszarze biegu jałowego oraz średnich prędkości (20-40 $\mathrm{m} / \mathrm{s})$ dla stałej prędkości $\left(\mathrm{a}=0 \mathrm{~m} / \mathrm{s}^{2}\right)$ (rys. 4$)$.

Niepowtarzalność przejazdów uwidoczniona jest większym udziałem biegu jałowego dla pojazdu A - udział tego stanu w całkowitym teście wynosi ok. $10 \%$ (dla pojazdu jest to ok. $12 \%$ ). Zbliżony (nie można uznać podobieństwa) jest także rozkład udziału czasu pracy dla większych prędkości pojazdu; dla pojazdu A jest on skupiony w zakresie 17-39 m/s, natomiast dla pojazdu B rozkład ten jest bardziej równomierny już od prędkości pojazdu $15 \mathrm{~m} / \mathrm{s}$.

Maksymalne natężenia emisji tlenku węgla (rys. 5), określone w miligramach na sekundę, rozłożone są w obszarze wszystkich wykorzystywanych prędkości pojazdu oraz jego przyspieszenia w zakresie od 
a)

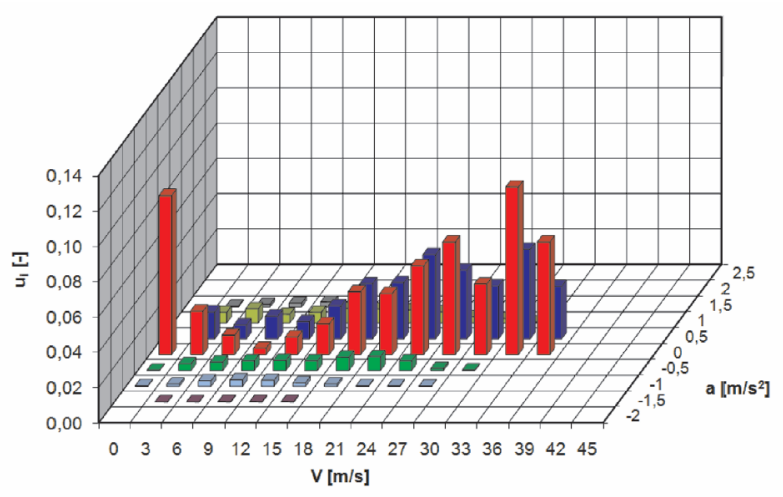

b)

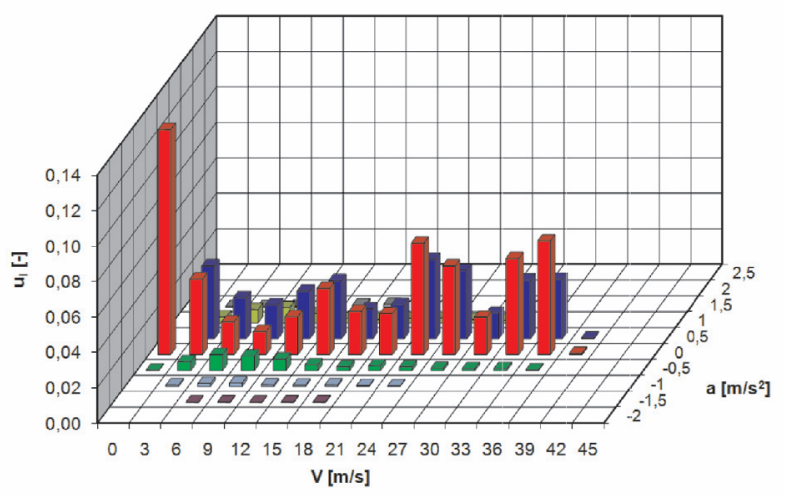

Fig. 4. The characteristics of the operating time share in the ranges of speeds and accelerations during the road tests: a) vehicle A, b) vehicle B Rys. 4. Charakterystyka udziału czasu pracy w przedziałach prędkości i przyspieszenia podczas badań drogowych: a) pojazd A, b) pojazd B

ranges thus obtaining the characteristics of the share of engine operation and the characteristics of the matrices of the individual exhaust emissions. The greatest share of the engine operation under the tested traffic conditions falls in the area of idle speed and medium speeds $(20-40 \mathrm{~m} / \mathrm{s})$ for a constant acceleration $\left(\mathrm{a}=0 \mathrm{~m} / \mathrm{s}^{2}\right)$ (Fig. 4$)$.

The lack of the repeatability of the drives is seen with a greater share of idle speed for vehicle A - the share of this state in the whole tests amounts to approximately $10 \%$ (for the vehicle it is approximately 12\%). The distribution of the operating time share for higher vehicle speeds is also alike; for vehicle A it oscillates around $17-39 \mathrm{~m} / \mathrm{s}$ and for vehicle $\mathrm{B}$ this distribution is more even starting from the speed of $15 \mathrm{~m} / \mathrm{s}$.

The maximum carbon monoxide emission rate (Fig. 5) given in milligrams per second falls within the area of all used vehicle speeds and its accelerations within the range of -1 to $2 \mathrm{~m} / \mathrm{s}^{2}$. These values are correlated with the vehicle acceleration: as the acceleration grows the emission of carbon monoxide grows as well. For vehicle A, however, (Euro 4) these are values several times higher than for vehicle B (Euro 5 ). For vehicle $B$ the emission of carbon monoxide strongly depends on the vehicle speed and such a clear maximum (for vehicle average speeds and maximum acceleration) is not observed as in the case of the previous vehicle.

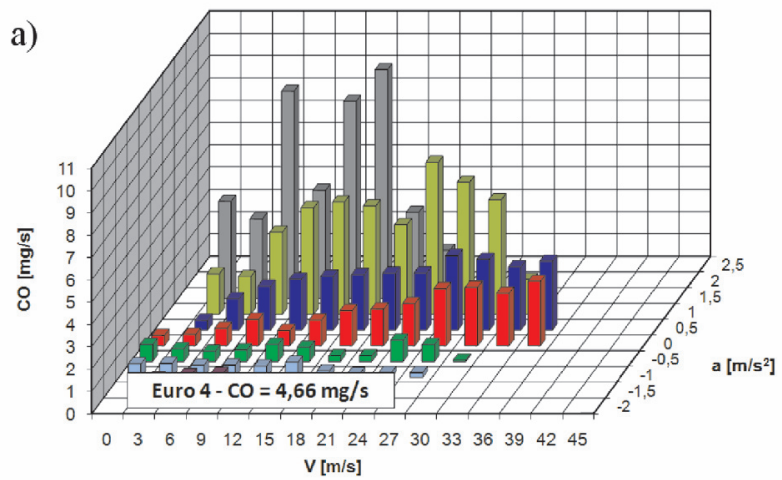

-1 do $2 \mathrm{~m} / \mathrm{s}^{2}$. Wartości te są skorelowane z przyspieszeniem pojazdu: w miarę wzrostu przyspieszenia wzrasta również emisja tlenku węgla. Jednakże dla pojazdu A, spełniającego normą Euro 4, są to wartości kilkakrotnie wyższe niż dla pojazdu typu B (norma Euro 5). Dla pojazdu B emisja tlenku węgla bardzo mocno zależy od prędkości jazdy i nie obserwuje się tak wyraźnego maksimum (dla średnich prędkości pojazdu i maksymalnego przyspieszenia), jak dla pojazdu poprzedniego.

Porównawczo na wykresach podano wartości średniego natężenia emisji danego składnika wynikającego $\mathrm{z}$ testu NEDC, np. emisja normatywna CO wynosi $500 \mathrm{mg} / \mathrm{km}$ (dla normy Euro 4/5); po przeliczeniu na średnią emisję sekundową uzyskuje się wynik 4,66 mg/s.

Odmiennie jest z emisją węglowodorów (rys. 6): dla pojazdu A znacząca występuje dla maksymalnych przyspieszeń i średniej prędkości pojazdu, w pozostałym obszarze jest znikoma. Dla pojazdu B zwiększona emisja HC występuje dla małych prędkości pojazdu w pełnym zakresie przyspieszenia. Należy jednak zauważyć, że jest ona porównywalna między pojazdami. Wynika to z takiego samego normatywnego limitu emisji węglowodorów.

Obszar zwiększonego natężenia emisji tlenków azotu pojazdu A (rys. 7a) przypada dla zakresu zwiększonych prędkości pojazdu oraz dla znacznego przyspieszenia po-

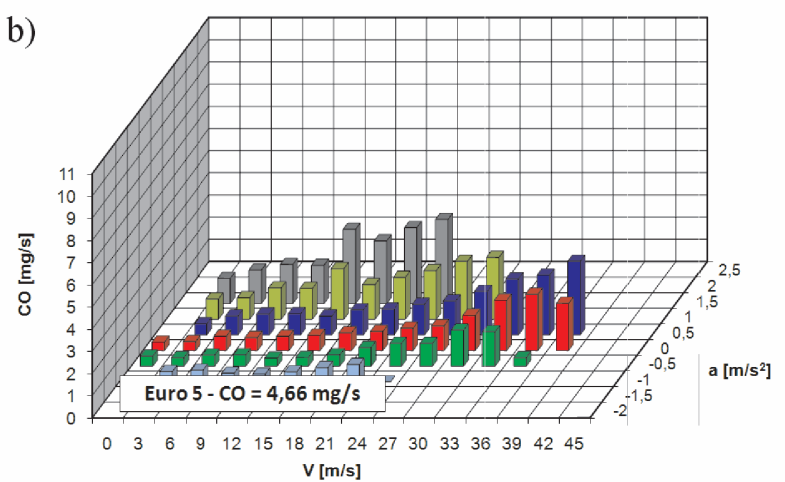

Fig. 5. The characteristics of the emission of carbon monoxide in the speed and acceleration ranges during the road tests: a) vehicle A, b) vehicle B Rys. 5. Charakterystyka emisji tlenku węgla w przedziałach prędkości i przyspieszenia podczas badań drogowych: a) pojazd A, b) pojazd B 

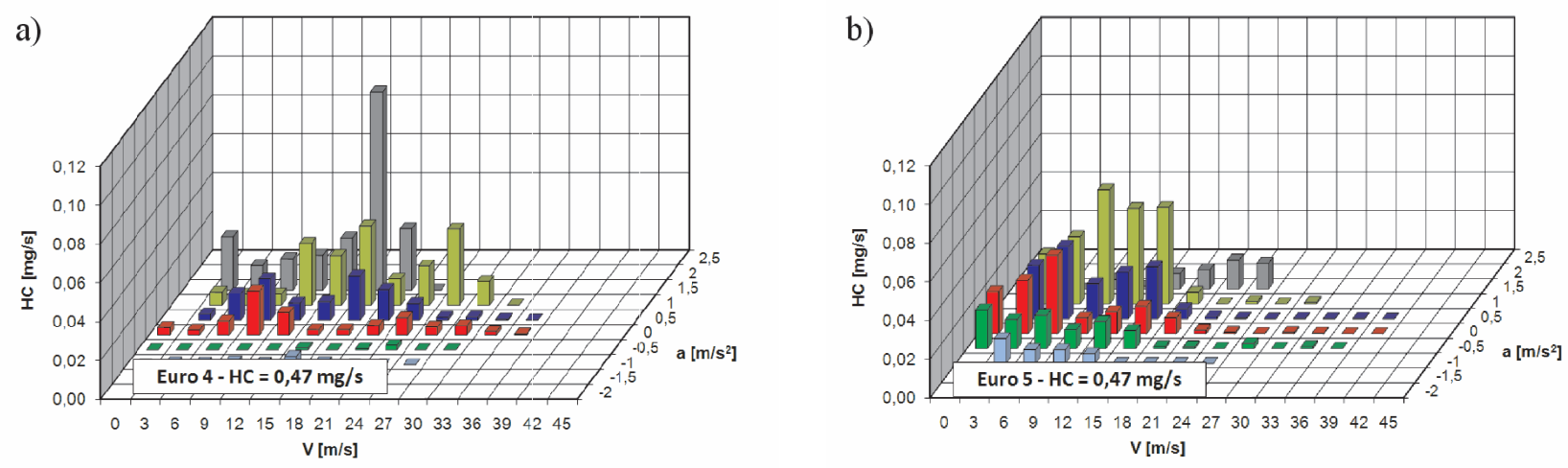

Fig. 6. The characteristics of the emission of hydrocarbons in the speed and acceleration ranges during the road tests: a) vehicle A, b) vehicle B Rys. 6. Charakterystyka emisji węglowodorów w przedziałach prędkości i przyspieszenia podczas badań drogowych: a) pojazd A, b) pojazd B
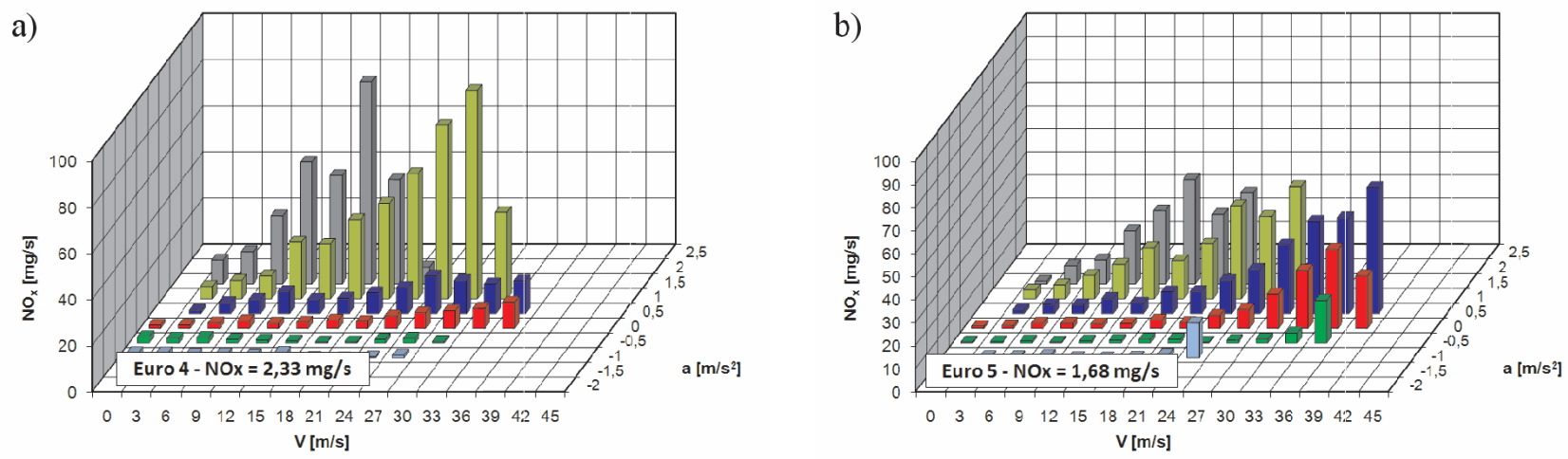

Fig. 7. The characteristics of the emission of nitric oxides in the speed and acceleration ranges during the road tests: a) vehicle $A$, b) vehicle $B$ Rys. 7. Charakterystyka emisji tlenków azotu w przedziałach prędkości i przyspieszenia podczas badań drogowych: a) pojazd A, b) pojazd B
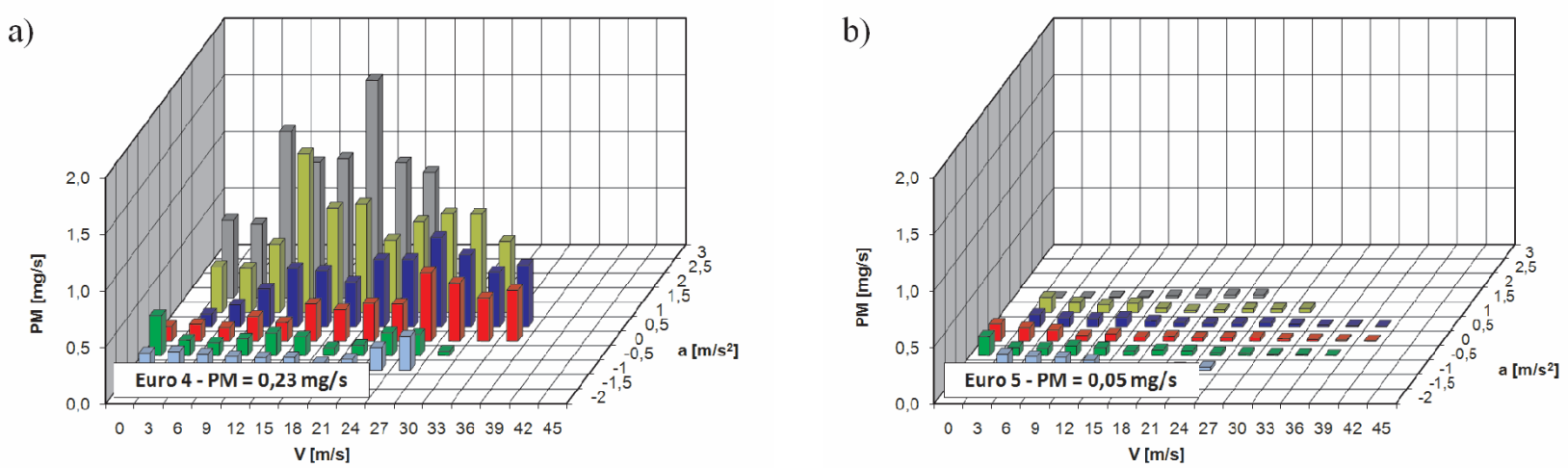

Fig. 8. The characteristics of the emissions of PM in the speed and acceleration ranges during the road tests: a) vehicle A, b) vehicle B Rys. 8. Charakterystyka emisji cząstek stałych w przedziałach prędkości i przyspieszenia podczas badań drogowych: a) pojazd A, b) pojazd B

For comparison, in the graphs the values of the emission rates of each exhaust component have been given that result from the NEDC test - normative emission of $\mathrm{CO}$ amounts to $500 \mathrm{mg} / \mathrm{km}$ (for Euro 4/5); after converting into the average emission per second we obtain a result of $4.66 \mathrm{mg} / \mathrm{s}$.

It is contrary for the emission of hydrocarbons (Fig. 6): for vehicle A significant emission of this component occurs for maximum accelerations and medium vehicle speed and in the other areas it is miniscule. For vehicle $\mathrm{B}$ an increased emission of hydrocarbons occurs for low vehicle speeds in the whole range of acceleration. We should note however jazdu, a więc znacznego obciążenia silnika. Związane jest to ze zwiększeniem dawki paliwa a jednocześnie wzrostem prędkości obrotowej silnika. Dla pojazdu B obserwowano dwukrotnie mniejszą emisję tlenków azotu (ok. $50 \mathrm{mg} / \mathrm{s}$ ), a jednocześnie emisja ta była większa dla maksymalnej wykorzystywanej prędkości (rys. 7b).

Emisja cząstek stałych ma inny charakter dla pojazdu A i B (rys. 8). Pojazd A niewyposażony w filtr cząstek stałych charakteryzuje się znacznie większą emisją niż pojazd B (rys. 8a). Wartości emisji w poszczególnych przedziałach różnią się około 20 razy. Filtr cząstek stałych stanowi skuteczną 
a)

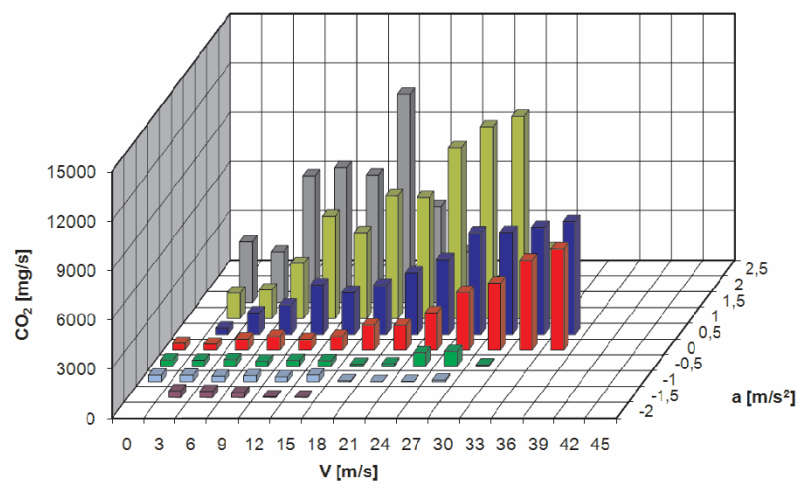

b)

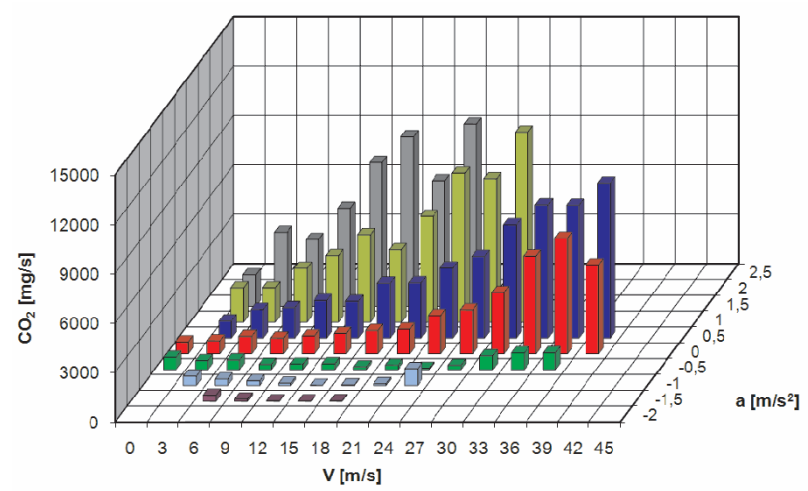

Fig. 9. The characteristics of the emission of carbon dioxide in the speed and acceleration ranges during the road tests: a) vehicle A, b) vehicle B Rys. 9. Charakterystyka emisji dwutlenku węgla w przedziałach prędkości i przyspieszenia podczas badań drogowych: a) pojazd A, b) pojazd B

that it is comparable between the vehicles. It results from the same normative $\mathrm{HC}$ emission limit.

The area of an increased nitric oxide emission rate of vehicle A (Fig. 7a) falls in the range of increased vehicle speeds and significant acceleration, hence high engine load. This is related to the increase in the fuel dose and the increase in the engine speed. For vehicle B twice-lower emission of nitric oxides was observed (approximately $50 \mathrm{mg} / \mathrm{s}$ ) and at the same time this emission was higher for the maximum used speed (Fig. 7b).

The emission of particulate matter is of different nature for vehicles A and B (Fig. 8). Vehicle A not fitted with DPF is characterized by a much larger emission of $\mathrm{PM}$ than vehicle B (Fig. 8a). The values of the emission in individual ranges are different approximately 20 times. DPF is an efficient method of the reduction of mass emission of PM, which is commonly applied in modern Euro 5 engines.

The emission of carbon dioxide (Fig. 9) is similar for the tested vehicles: it grows as the vehicle speed and acceleration grow. The maximum values are comparable for both vehicles - they amount to approximately $10000 \mathrm{~g} / \mathrm{s}$ and at idle this emission is approximately $500-800 \mathrm{mg} / \mathrm{s}$.

\section{The characteristics of the PM emission in terms of their size}

Additionally within the on-road tests in real traffic a size-related analysis of the PM was performed. For the comparison the ranges of engine operation were used that are most frequently utilized under real traffic conditions. They correspond to four areas of operation (Fig. 10): $1-$ idle speed, 2 - medium engine speed-low load, 3 - medium engine speed-medium load, 4 - high engine speed-high engine load. The vehicles were fitted with different powertrains, hence the selected ranges of operation do not overlap (similar areas were compared: as a criterion of similarity the relative engine speed and relative engine load were selected referred to the maximum values). For vehicle $A$ the most of the measuring points (Fig. 10a) fall in the range of high engine speeds and high engine load (area 4). For vehicle B the points are distributed in a different way: their high number metodę ograniczania emisji masowej cząstek stałych, która powszechnie stosowana jest obecnie w pojazdach spełniających normę Euro 5.

Emisja dwutlenku węgla (rys. 9) ma zbliżony charakter dla badanych pojazdów: zwiększa się w miarę wzrostu prędkości i przyspieszenia pojazdu. Maksymalne wartości są ze sobą porównywalne - wynoszą one ok. $10000 \mathrm{~g} / \mathrm{s}$, natomiast na biegu jałowym emisja ta wynosi ok. 500-800 mg/s.

\section{Charakterystyka wymiarowej emisji cząstek stałych}

Dodatkowo w ramach badań drogowych w rzeczywistych warunkach ruchu dokonano analizy emisji wymiarowej cząstek stałych. Do porównania wykorzystano zakresy pracy silnika, które w największym stopniu są wykorzystywane podczas rzeczywistych warunków ruchu. Odpowiadają one czterem obszarom pracy (rys. 10): 1 - bieg jałowy silnika, 2 - średnia prędkość obrotowa-małe obciążenie, 3 - średnia prędkość obrotowa-średnie obciążenie, 4 - duża prędkość obrotowa-duże obciążenie silnika. Pojazdy wyposażone były w różne jednostki napędowe, w związku z tym wybrane zakresy pracy nie pokrywają się (porównano obszary podobne: za kryterium podobieństwa wybrano względną prędkość obrotową i względne obciążenie odniesione do wartości maksymalnych). Dla pojazdu A większość punktów pomiarowych (rys. 10a) przypada na zakres znacznych prędkości obrotowych i dużego obciążenia (obszar 4). Dla pojazdu B punkty są rozłożone w inny sposób: znaczna ich liczba występuje dla średniej prędkości i średniego obciążenia (obszary 2 i 3 na rys. 10b) oraz zakres dużych prędkości obrotowych i dużego obciążenia (obszar 4 na rys. 10b).

Dla tak wydzielonych charakterystycznych obszarów pracy silnika dokonano analizy wymiarowej cząstek stałych przypadających na dany zakres średnic cząstek (dla pojazdu A bez filtra cząstek stałych - rys. 11):

- zakres 1 (bieg jałowy silnika) - cząstki z zakresu średnic 10-100 nm są rozłożone równomiernie $\mathrm{z}$ większą przewagą liczbową cząstek o średnicach większych (ok. 60-80 $\mathrm{nm}$ ); koncentracja cząstek dla przyjętego obszaru pracy w każdym przedziale wymiarowym wynosi $0,8-1 \times 10^{6} \mathrm{~cm}^{-3}$; 

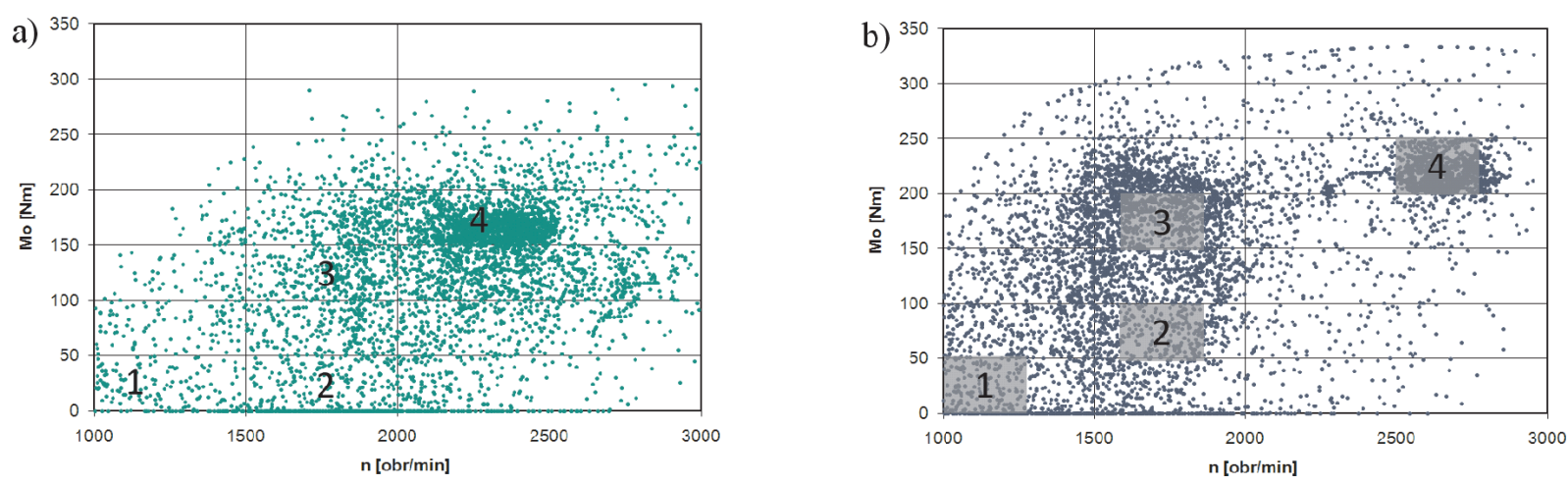

Fig. 10. Engine operating conditions in the coordinates of engine speed - engine load in the on-road tests: a) vehicle A, b) vehicle B (the digits denote the area of operation for which the PM size distribution was determined)

Rys. 10. Warunki pracy silnika we wspótrzędnych prędkość obrotowa-obciązenie podczas badań drogowych: a) pojazd A, b) pojazd B (cyfry oznaczaja obszary pracy, dla których wyznaczono rozkład wymiarowy PM)

occurs for medium speeds and medium loads (areas 2 and 3 in Fig. 10b) and the rage of high engine speeds and high engine loads (area 4 in Fig. 10b).

For such distinguished characteristics of the area of engine operation the size-related analysis of PM was performed falling within a given range of PM diameter (for vehicle A not fitted with the DPF - Fig. 11):

- range 1 (idle speed) - PM in the diameter range 10-100 nm is distributed evenly with the particles of diameter $60-80$ $\mathrm{nm}$ prevailing; the concentration of the PM for the assumed work area in each size range amounts to $0.8-1 \times 10^{6}$ $\mathrm{cm}^{-3}$; this results from a high air excess coefficient and a sufficient time for the combustion of a minimum fuel dose;

- range 2 (medium engine speed-low load) - particles in the range $10-100 \mathrm{~nm}$ where the maximum falls within the range of approximately $20 \mathrm{~nm}$; the concentration of PM for the diameters of approximately $20 \mathrm{~nm}$ (the highest share of such particles in the exhaust gases) amounts to $7-8 \times 10^{6} \mathrm{~cm}^{-3}$;

- range 3 (medium engine speed-medium load) - particles in the range 7-100 nm where the maximum falls within approximately $10 \mathrm{~nm}$ and $40-60 \mathrm{~nm}$; the concentration of particles for these size ranges is $0.8-1 \times 10^{6}$ $\mathrm{cm}^{-3}$; the values similar to the values of idle speed are a result of a high air excess coefficient (supercharged engine) and high fuel injection pressure (approximately 1300 bar);

- range 4 (high engine speed-high load) - the particles in the range $7-150 \mathrm{~nm}$; the maximum falls within the range of 40-100 nm; the concentration of particles for this size range amounts to $3.5-4 \times 10^{6} \mathrm{~cm}^{-3}$; the particle diameter characteristics values of this operating range refer to the larger particles than in previous cases-this results from a greater fuel dose, lower air excess coefficient and shorter time of fuel dose combustion.

For vehicle B fitted with DPF the size related analysis of PM (Fig. 12) is different in terms of size and concentration (here we have lower values of particle count in most of the size ranges): wynika to $\mathrm{z}$ dużego współczynnika nadmiaru powietrza i wystarczającego czasu do spalenia minimalnej dawki paliwa;

- zakres 2 (średnia prędkość obrotowa-małe obciążenie) cząstki z zakresu $10-100 \mathrm{~nm}$, gdzie maksimum przypada na zakres ok. $20 \mathrm{~nm}$; koncentracja cząstek dla przedziałów średnic ok. $20 \mathrm{~nm}$ (największy udział takich cząstek stałych w spalinach) wynosi $7-8 \times 10^{6} \mathrm{~cm}^{-3}$;

- zakres 3 (średnia prędkość obrotowa-średnie obciążenie) - cząstki z zakresu 7-100 nm, gdzie maksimum przypada na zakresy ok. $10 \mathrm{~nm}$ i 40-60 nm; koncentracja cząstek dla tych przedziałów średnic wynosi $0,8-1 \times 10^{6} \mathrm{~cm}^{-3}$; wartości te zbliżone do wartości biegu jałowego są spowodowane dużym nadmiarem powietrza (silnik doładowany) i dużym ciśnieniem wtrysku paliwa (ok. 1300 bar);

- zakres 4 (duża prędkość obrotowa-duże obciążenie) cząstki z zakresu 7-150 nm; maksimum przypada na zakres 40-100 nm; koncentracja cząstek dla tego przedziału średnic wynosi $3,5-4 \times 10^{6} \mathrm{~cm}^{-3}$; wartości charakterystyczne średnicy cząstek tego zakresu pracy dotyczą większych cząstek niż w poprzednich przypadkach wynika to głównie z większej dawki paliwa, mniejszego współczynnika nadmiaru powietrza i krótszego czasu spalania dawki paliwa.

Dla pojazdu B wyposażonego w filtr cząstek stałych analiza wymiarowa emisji cząstek stałych (rys. 12) ma charakter odmienny pod względem zarówno wymiarowym, jak i pod względem koncentracji (występują tu niższe wartości liczności cząstek w większości przedziałów wymiarowych):

- zakres 1 (bieg jałowy silnika) - średnica charakterystyczna cząstek (o największej liczności) to zakres ok. $30 \mathrm{~nm}$; koncentracja dla tego przedziału to $1 \times 10^{6} \mathrm{~cm}^{-3}$;

- zakres 2 (średnia prędkość obrotowa-małe obciążenie) - cząstki z zakresu 10-30 nm; koncentracja cząstek dla wymienionego przedziału $4-5 \times 10^{6} \mathrm{~cm}^{-3}$;

- zakres 3 (średnia prędkość obrotowa-średnie obciążenie) - cząstki z zakresu 10-100 nm, gdzie maksimum przypada na zakresy ok. $10 \mathrm{~nm}$; koncentracja cząstek dla tego przedziału wynosi $1,5-2,2 \times 10^{6} \mathrm{~cm}^{-3}$; 
- range 1 (idle speed) - the characteristic diameter of the particles (particles highest in number) is the range of approximately $30 \mathrm{~nm}$; the concentration of PM for this range is $1 \times 10^{6} \mathrm{~cm}^{-3}$;

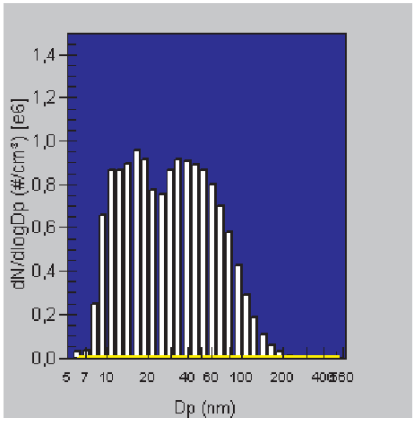

- zakres 4 (duża prędkość obrotowa-duże obciążenie) cząstki z zakresu 10-150 nm; maksimum przypada na zakres 30-50 nm; koncentracja cząstek dla tego przedziału średnic wynosi ok. $3 \times 10^{6} \mathrm{~cm}^{-3}$.

3

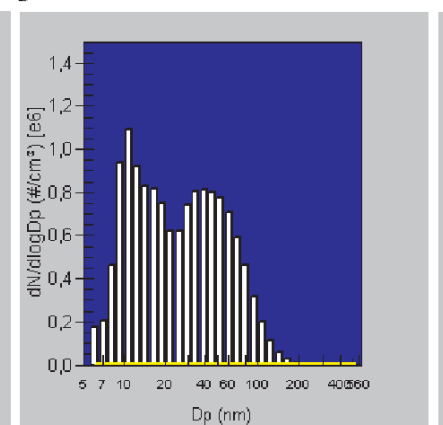

4

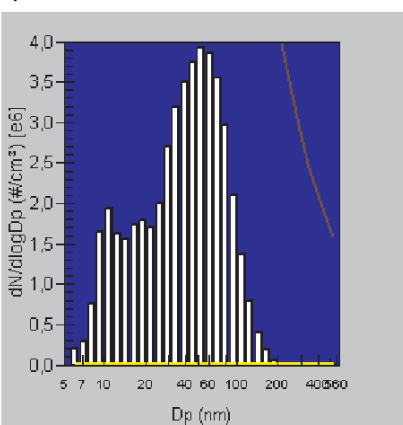

Fig. 11. On-road test PM size distribution under traffic conditions for vehicle A without DPF (area of engine operation determined in Fig. 10a): 1 - idle speed, 2 - medium engine speed-low load, 3 - medium engine speed-medium load, 4 - high engine speed-high load

Rys. 11. Rozkład wymiarowy czastek stałych w rzeczywistych warunkach ruchu dla pojazdu A bez filtra czastek statych (obszary pracy silnika określone na rys. 10a): 1 - bieg jałowy, 2 -średnia prędkość obrotowa-małe obciażenie, 3 - średnia prędkość obrotowa-średnie obciążenie, 4 -duża prędkość obrotowa-duże obciążnie

- range 2 (medium engine speed-low load) - particles in the range $10-30 \mathrm{~nm}$; the concentration of $\mathrm{PM}$ for this range is $4-5 \times 10^{6} \mathrm{~cm}^{-3}$;

- range 3 (medium engine speed-medium load) - particles in the range $10-100 \mathrm{~nm}$, the maximum falls within the range of approximately $10 \mathrm{~nm}$; the concentration of PM for this range is $1.5-2.2 \times 10^{6} \mathrm{~cm}^{-3}$;

- range 4 (high engine speed-high load) - particles in the range $10-150 \mathrm{~nm}$; the maximum falls within the range of approximately $30-50 \mathrm{~nm}$; the concentration of PM for this ranges is approximately $3 \times 10^{6} \mathrm{~cm}^{-3}$.

During the road tests for vehicle B fitted with DPF, Euro 5 compliant, the authors also observed the process of DPF regeneration that took place under the conditions of expressway traffic at the speed of approximately $120 \mathrm{~km} / \mathrm{h}$ (Fig. 13).

This was the process of full regeneration (total duration approximately $10 \mathrm{~min}$ ). The size-related analysis of the PM emission shows a significant emission of PM during this
Podczas badań drogowych dla pojazdu B wyposażonego w filtr cząstek stałych, spełniającego normę Euro 5, zaobserwowano również proces regeneracji filtra cząstek stałych, który przebiegał w warunkach jazdy autostradowej przy prędkości pojazdu ok. $120 \mathrm{~km} / \mathrm{h}$ (rys. 13).

Był to proces regeneracji pełnej (całkowity czas trwania ok. $10 \mathrm{~min}$ ). Analiza wymiarowa emisji cząstek stałych uwidacznia emisję znacznej liczby cząstek stałych podczas tego procesu: początek regeneracji charakteryzuje się zwiększoną emisją cząstek o wymiarach $20-30 \mathrm{~nm}\left(\mathrm{ok} .8 \times 10^{5} \mathrm{~cm}^{-3}\right)$,

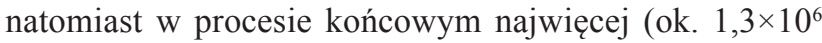
$\mathrm{cm}^{-3}$ ) emitowanych jest cząstek mniejszych - o średnicy charakterystycznej ok. $10 \mathrm{~nm}$.

Pod względem całkowitej liczby cząstek stałych proces regeneracji filtra cząstek stałych zwiększa tę wartość około 10-krotnie: w warunkach ustalonych jazdy autostradowej całkowita koncentracja cząstek stałych wynosiła ok. $0,5-1 \times 10^{5} \mathrm{~cm}^{-3}$ (z pominięciem stopnia rozcieńczenia), a w czasie regeneracji wartość ta zwiększała się do $4-5 \times 10^{5} \mathrm{~cm}^{-3}$.
1

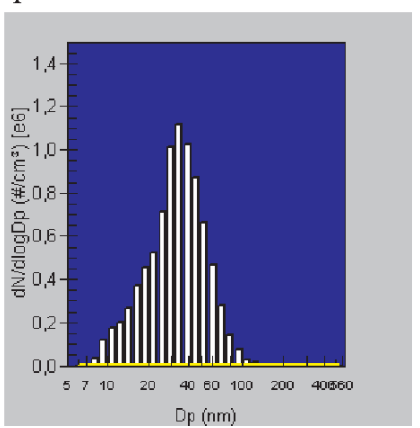

2

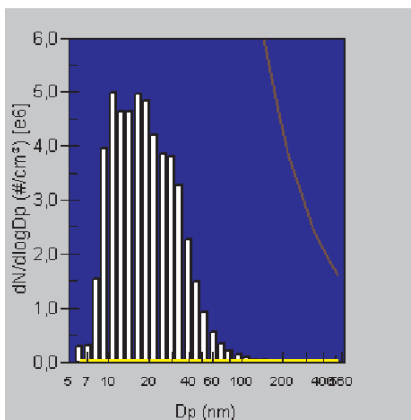

3

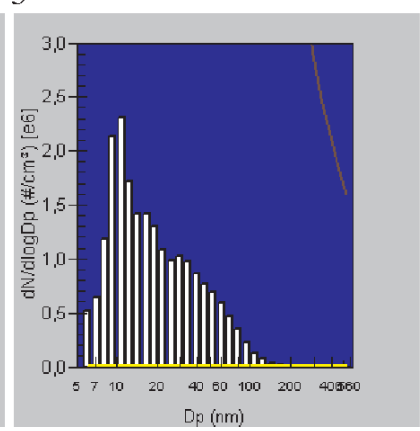

4

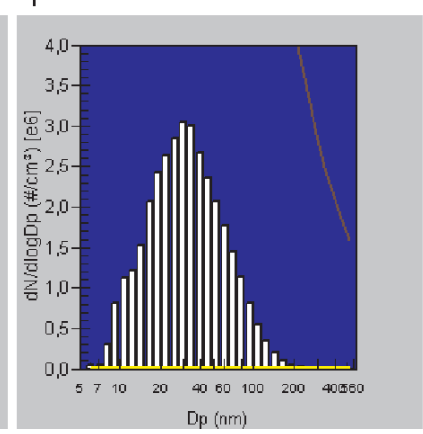

Fig. 12. On-road test PM size distribution under traffic conditions for vehicle B fitted with DPF (area of engine operation determined in fig. 10a): 1 - idle speed, 2 - medium engine speed-low load, 3 - medium engine speed-medium load, 4 - high engine speed-high load

Rys. 12. Rozkład wymiarowy cząstek statych w rzeczywistych warunkach ruchu dla pojazdu B z filtrem cząstek statych (obszary pracy określone na rys. 10b): 1 - bieg jałowy, 2 -średnia prędkość obrotowa-małe obciażenie, 3 -średnia prędkość obrotowa-średnie obciażenie, 4 -duża prędkość obrotowa-duże obciążenie 


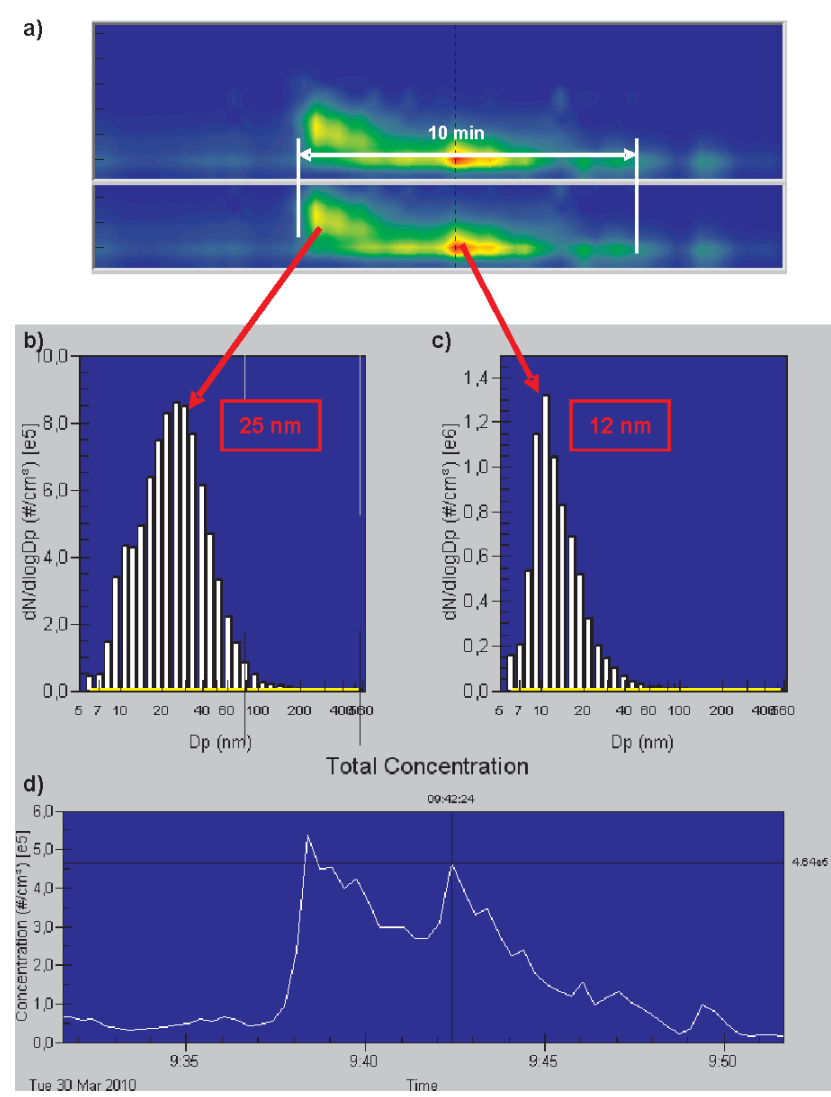

Fig. 13. The recorded process of DPF regeneration, vehicle B Rys. 13. Zarejestrowany proces regeneracji filtra czastek statych, pojazd B

process: the onset of the regeneration is characterized by an increased emissions of PM of the size of 20-30 nm (ok. $8 \times 10^{5}$ $\mathrm{cm}^{-3}$ ) and in the final phase (approximately $1.3 \times 10^{6} \mathrm{~cm}^{-3}$ ), the highest number of PM smaller in diameter is observed of the diameter of approximately $10 \mathrm{~nm}$.

In terms of the total number of particles the regeneration process increases this value approximately 10 times: under steady states of expressway drive the total concentration of particles was approximately $0.5-1 \times 10^{5} \mathrm{~cm}^{-3}$ (dilution level excluded) and during the regeneration process this value increased to $4-5 \times 10^{5} \mathrm{~cm}^{-3}$.

The first period of regeneration (initial 3-4 min) is characterized with a greater range of the emitted PM (7-100 nm) and in the subsequent period (4-10 $\mathrm{min})-\mathrm{PM}$ of smaller diameter variability range occur $(5-25 \mathrm{~nm})$.

It is noteworthy that no significant mass growth of PM was recorded in this period. The normative values of the PM emission determined by the Euro 5 standard allow for the regeneration of the DPF filter hence the limit value cannot be exceeded irrespective of the fact whether the process occurs in the vehicle or not.

\section{Quantitative emission indicators}

The obtained results of the duration of the road tests served for the verification of the hypothesis on the fulfillment or non-fulfillment of the normative regulations on the on-road emissions. Such a comparison served to determine the value of growth or reduction of the on-road vehicles
Pierwszy okres regeneracji (początkowe 3-4 min) charakteryzuje się większym zakresem emitowanych cząstek (7-100 nm), w kolejnym natomiast (4-10 min) - powstają cząstki o mniejszym zakresie zmienności średnic (5-25 $\mathrm{nm})$.

Należy zaznaczyć, że nie odnotowano znaczącego wzrostu masy cząstek stałych w tym okresie. Wartości normatywne emisji cząstek stałych określone normą Euro 5 przewidują regenerację filtra cząstek stałych, a więc wartość limitu nie może być przekroczona, niezależnie czy proces ten zachodzi w pojeździe, czy też nie.

\section{Ilościowe wskaźniki emisji}

Uzyskane wyniki czasu testów drogowych posłużyły do weryfikacji hipotezy o spełnianiu (lub nie) normatywnych przepisów emisji w rzeczywistych warunkach użytkowania pojazdów. Porównanie takie posłużyło do określenia wielkości zwiększenia lub zmniejszenia emisji z pojazdu w warunkach rzeczywistych w stosunku do warunków użytkowania pojazdu w teście homologacyjnym.

Z przedstawionych wyników natężenia emisji (zaznaczone kolorem czerwonym na kolejnych rysunkach) dowolnego związku można obliczyć krotność zwiększenia/zmniejszenia emisji w rzeczywistych warunkach ruchu w stosunku do wartości normatywnych. Krotność tę zdefiniowano jako wskaźnik emisji pojazdu (dla danego związku szkodliwego) - równanie (1), gdzie: j - związek szkodliwy, dla którego określono wskaźnik emisji, $\mathrm{E}_{\text {rzecz,j }}$ - emisja drogowa w warunkach rzeczywistych od początku testu do chwili bieżącej $\mathrm{w} \mathrm{g} / \mathrm{km}, \mathrm{E}_{\text {norma,j }}$ - emisja drogowa normatywna według Euro $4 / 5 \mathrm{w} \mathrm{g} / \mathrm{km}$.

Wskaźnik określony w ten sposób można obliczyć jako wartość:

- chwilową (na kolejnych rysunkach zaznaczono kolorem zielonym) - wskaźnik cechuje duża zmienność, gdyż jest obliczany w każdej sekundzie testu;

- narastającą w trakcie wykonywania testu; wskaźnik jest obliczany jako bieżąca emisja drogowa danego związku szkodliwego (od początku testu do chwili bieżącej) w stosunku do wartości normatywnej; wartość tę zaznaczono na kolejnych rysunkach kolorem niebieskim;

- odnoszącą się do całego testu badawczego, jako stosunek emisji drogowej w teście drogowym wykonywanym w rzeczywistych warunkach ruchu do wartości normatywnej.

Wskaźnik emisji danego związku szkodliwego może przyjmować wartości z przedziału $\langle 0, \infty)$. Oznacza to, że jeżeli emisja z pojazdu nie przekracza wartości normatywnych, wskaźnik ma wartość mniejszą od jedności, natomiast przy przekroczeniu wartości normatywnej wskaźnik jest większy od jedności, przy równości emisji rzeczywistej i normatywnej wskaźnik wynosi 1.

$\mathrm{Na}$ wykresach z rys. 14 przedstawiono dla każdego związku szkodliwego zakres zmian wskaźnika emisji, dla którego spełniony jest limit normatywny (kolor szary).

Pomimo dużej chwilowej zmienności wskaźnika emisji,jego wartość określona w sposób narastający charakteryzuje się:

- dla tlenku węgla - bardzo gwałtowny wzrost podczas uruchomienia silnika i następnie zmniejszenie jego war- 
emissions as opposed to the homologation tests.

From the presented results of the emission rate (marked red on the figures) of any given component we can calculate the multiplicity of the growth or reduction in the on-road emissions as opposed to the normative values. This multiplicity was defined as an indicator of the vehicle emission (for each given exhaust component):

$$
\mathrm{k}_{\mathrm{j}}=\frac{\sum_{0}^{\mathrm{t}} \mathrm{E}_{\mathrm{rzecz}, \mathrm{j}}}{\mathrm{E}_{\text {norma }, \mathrm{j}}}
$$

where: $\mathrm{j}$ - exhaust component, for which the emision indicator was determined, $\mathrm{E}_{\mathrm{rzecz,j}}$ - onroad emission under real traffic from the start of the test $(\mathrm{g} / \mathrm{km}), \mathrm{E}_{\text {norma,j }}$ - normative on-road emission according to Euro 4/5 (g/km).

If we have an indicator determined in this way we can calculate its value:

- instantaneous (in figures marked green) characterized by high variability, as it is calculated in each second of the test;

- incrementing while the test is performed; it is calculated as the on-going on-road emission of a given exhaust component (from the start of the test) as compared to the normative value; this value is marked blue in the figures;

- related to the whole test as a ratio of the on-road emission under real traffic to the normative emission.

The emission indicator of a given exhaust component can assume values from the range of $\langle 0, \infty)$. This means that if the vehicle emission does not exceed the normative values, the indicator has a value lower than 1 and when the normative value is exceeded the indicator is greater than 1 . If the values are equal (on-road and normative) the indicator is 1 .

In the graphs from Fig. 14 for each exhaust component (for which the normative limit is fulfilled) the change of the emission indicator has been presented (gray).

Despite high momentary variability of the emission indicator its value determined in an incrementing way is characterized as follows:

- for carbon monoxide - abrupt growth during engine start and then lowering of its value; under traffic conditions in a short time a reduction of this emission is obtained below the required standard for both vehicle $\mathrm{A}$ and $\mathrm{B}$; the indicator values are similar for both tested vehicles (Fig. 14a),

- for hydrocarbons - the course of the changes of the indicator is similar to that recorded for carbon monoxide but
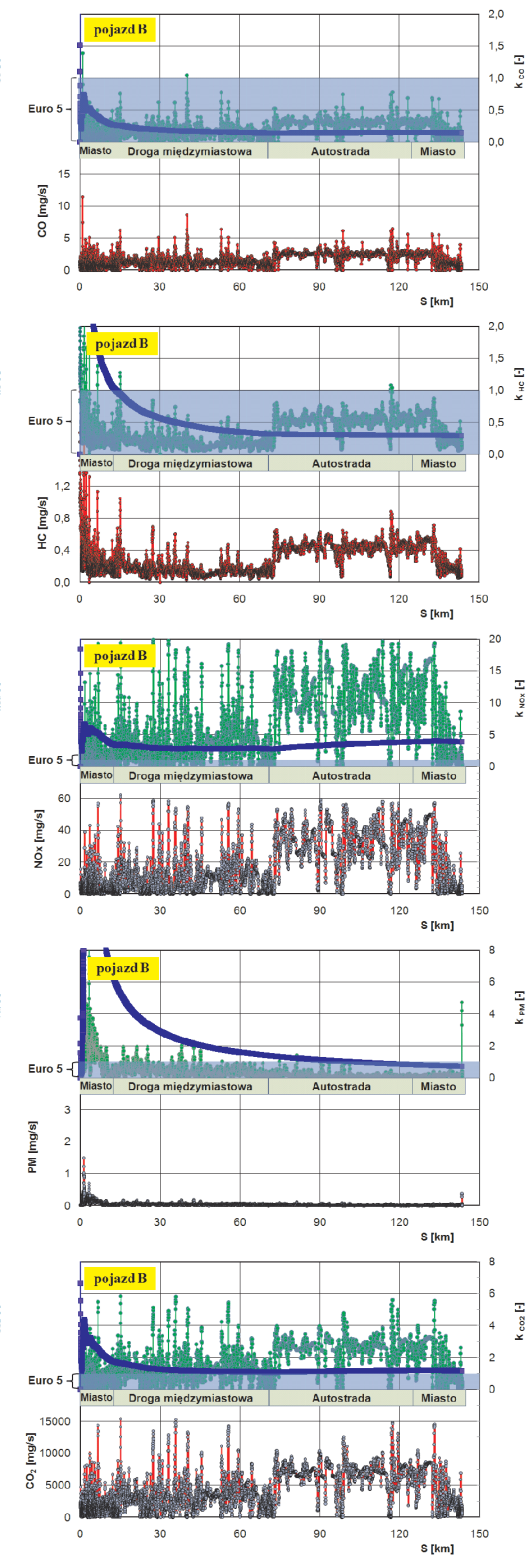

Fig. 14. The characteristics of the on-road exhaust emissions: a) $\mathrm{CO}, \mathrm{b}$ ) $\mathrm{HC}$, c) $\mathrm{NO}_{x}$, d) $\mathrm{PM}$, e) $\mathrm{CO}_{2}$ for vehicles $\mathrm{A}$ and $\mathrm{B}$ as functions of the covered distance

Rys. 14. Charakterystyka emisji związków szkodliwych podczas badań drogowych: a) CO, b) $\mathrm{HC}$, c) $\mathrm{NO}_{x^{\prime}}$ d) $\mathrm{PM}$, e) $\mathrm{CO}_{2}$ dla pojazdu A i B jako funkcji przebytej drogi

tości; w warunkach rzeczywistej eksploatacji w krótkim okresie uzyskiwane jest zadowalające zmniejszenie emisji poniżej wymaganej normy zarówno dla pojazdu A, jak i $\mathrm{B}$; wartości wskaźnika są porównywalne dla badanych pojazdów (rys. 14a),

- dla węglowodorów - przebieg zmian wskaźnika jest podobny do wskaźnika jaki odnotowano przy tlenku węgla, jednakże pojazd A wymagał krótszego dystansu (ok. $2 \mathrm{~km}$ ), aby wartość wskaźnika była mniejsza od 1, dla pojazdu B dystans ten wynosił ok. $10 \mathrm{~km}$ (rys. 14b),

- dla tlenków azotu - brakiem spełniania wymagań normatywnych - wynika to głównie z różnicy pracy silnika pojazdu w teście NEDC i w warunkach rzeczywistych; nieznaczny dystans w teście badawczym skutkuje niepełnym nagrzaniem silnika, co w konsekwencji wyrażone jest małą emisją tlen- 
vehicle A required a shorter distance (approximately $2 \mathrm{~km}$ ) to reach the value of the indicator below 1 , for vehicle $\mathrm{B}$ this distance was approximately $10 \mathrm{~km}$ (Fig. 14b),

- for the nitric oxides - no normative requirement fulfilled - this results from the fact that there is a difference in the engine operation under the NEDC test and in the real traffic; a small distance in the test results in an incomplete warming up of the engine, which leads to a small emission of the nitric oxides for both vehicles $\mathrm{A}$ and $\mathrm{B}$. The value of the emission indicator is greater than 1 (Fig. 14c),

- for the particulate matter - the course of the changes of the emission indicator is different for the two vehicles: vehicle A was characterized by a very quick reaching of the indicator $\mathrm{k}<1$ (PM limit for Euro 4 is $25 \mathrm{mg} / \mathrm{km}$ ) and for vehicle B the indicator lower than 1 was reached after approximately $40 \mathrm{~km}$ despite the fact that the vehicle was fitted with DPF; this is due to a very low value of the limit for the Euro 5 standard (5 mg/km);

- for carbon dioxide - a normative value was assumed for comparison that amounts to $160 \mathrm{~g} / \mathrm{km}$ (average value of the emission from SUV vehicles in 2010 even though it is not determined for a single vehicle); the value of the $\mathrm{CO}_{2}$ emission indicator was more than 1 under real traffic conditions due to a high capacity of the tested engines $\left(2\right.$ and $\left.2.2 \mathrm{dm}^{3}\right)$.

The obtained emission indicators for the whole test (for vehicles A and B) characterize the vehicle on-road emission level against the emission standards that applied to a given vehicle (Fig. 15). The emission indicator of carbon monoxide $\left(\mathrm{k}_{\mathrm{CO}}=0.1-0.2\right)$, hydrocarbons $\left(\mathrm{k}_{\mathrm{HC}}=0.2-0.3\right)$ and PM $\left(\mathrm{k}_{\mathrm{PM}}=0.7-0.9\right)$ for the tested vehicles confirms that the vehicles do not exceed the average emissions in the on-road operation against the emission standards. The situation is quite contrary for the nitric oxides: for vehicle A, Euro 4 compliant, the emission indicator is 1.8 , which confirms a much higher emission against the emission standard; for vehicle B this indicator is 3.9 - the average emission is several times higher against Euro 5. For comparison the authors also determined this indicator for carbon dioxide - it exceeded the standard values during the on-road tests by $10-20 \%$ (the assumed value $160 \mathrm{~g} / \mathrm{km}$ corresponds to a fuel consumption of approximately $6.5 \mathrm{dm}^{3} / 100 \mathrm{~km}$ ).

\section{Conclusions}

From the analysis of the data it results that the normative emission values for the tested SUV vehicles meeting different Euro emission standards and the on-road exhaust emission vary. These differences in the case of some exhaust components under analysis are significant - these are as follows:

- For the Euro 4 compliant vehicle:

- The CO emission is lower by $80 \%$,

- The HC emission is lower by $80 \%$,

- The $\mathrm{NO}_{\mathrm{x}}$ emission is higher by $80 \%$,

- The PM emission is lower by $10 \%$,

- The $\mathrm{CO}_{2}$ emission is higher by $10 \%$, ków azotu; zarówno dla pojazdu A, jak również B wartość wskaźnika emisyjności jest większa od jedności (rys. 14c),

- dla cząstek stałych - przebieg zmian wskaźnika nie pokrywa się dla badanych pojazdów: pojazd A charakteryzował się bardzo szybkim osiągnięciem wskaźnika $\mathrm{k}<1$ (limit PM dla Euro 4 wynosi $25 \mathrm{mg} / \mathrm{km}$ ), natomiast dla pojazdu B wskaźnik mniejszy od jedności osiągnięto po ok. 40 $\mathrm{km}$, pomimo wyposażenia pojazdu w filtr cząstek stałych; spowodowane jest to bardzo małą wartością limitu emisji składnika dla normy Euro 5 (5 mg/km);

- dla dwutlenku węgla - przyjęto porównawczo wartość normatywną wynoszącą $160 \mathrm{~g} / \mathrm{km}$ (wartość średnia emisji z pojazdów typu SUV w 2010 roku, choć nie jest określana dla pojedynczego pojazdu); wartość wskaźnika emisji $\mathrm{CO}_{2}$ wynosiła powyżej jedności podczas badań w warunkach rzeczywistych ze względu na dużą pojemność skokową badanych silników (2 i 2,2 $\mathrm{dm}^{3}$ ).

Uzyskane wartości wskaźnika emisji obliczone dla całego testu (dla pojazdu A i B) charakteryzują emisyjność pojazdu w rzeczywistych warunkach użytkowania tych pojazdów w odniesieniu do normy emisji spalin, którą pojazd powinien spełniać (rys. 15). Wartość wskaźnika emisji tlenku węgla $\left(\mathrm{k}_{\mathrm{CO}}=0,1-0,2\right)$ i węglowodorów $\left(\mathrm{k}_{\mathrm{HC}}=0,2-0,3\right)$ oraz cząstek stałych $\left(\mathrm{k}_{\mathrm{PM}}=\right.$ $0,7-0,9)$ dla badanych pojazdów świadczy o nieprzekraczaniu średniej emisji tych składników w rzeczywistych warunkach drogowych w stosunku do wartości normatywnych. Odmiennie jest dla emisji tlenków azotu: dla pojazdu A, spełniającego normę Euro 4, wskaźnik emisji wynosi 1,8, co świadczy o znacznie większej emisji w stosunku do normy; dla pojazdu B wskaźnik ten wynosi 3,9 - średnia emisja jest kilkakrotnie wyższa w stosunku do normy toksyczności spalin Euro 5. Porównawczo również określono ten wskaźnik dla emisji dwutlenku węgla był on przekroczony podczas testu w rzeczywistych warunkach ruchu o 10-20\% (przyjęta wartość $160 \mathrm{~g} / \mathrm{km}$ odpowiada zużyciu paliwa ok. $\left.6,5 \mathrm{dm}^{3} / 100 \mathrm{~km}\right)$.

\section{Podsumowanie}

Z analizy danych wynika, że wartości emisji normatywnej dla badanych pojazdów typu SUV, spełniających różne

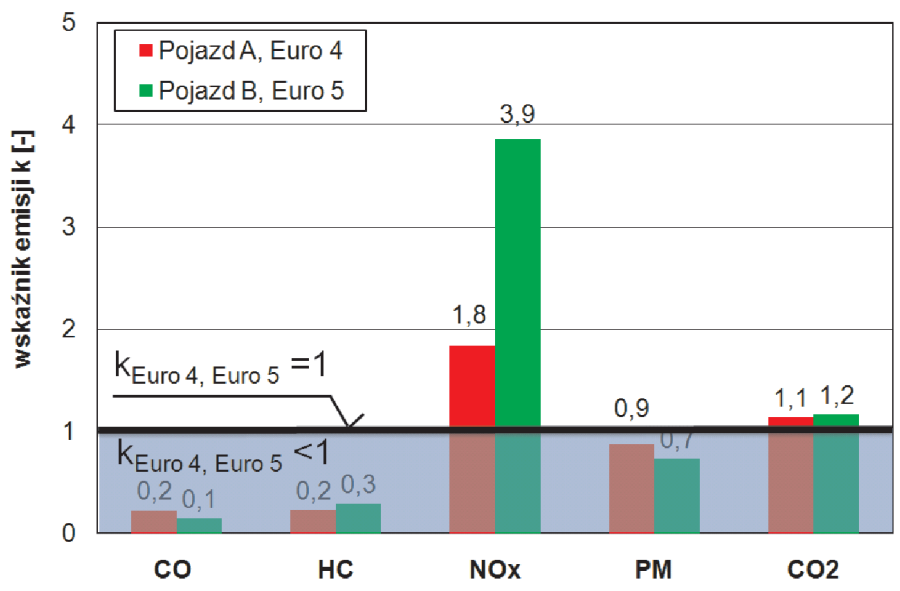

Fig. 15. The comparison of the emission indicators from SUV vehicles meeting different Euro emission standards

Rys. 15. Porównanie wskaźnika emisji pojazdów typu SUV, spetniających różne normy toksyczności spalin 
- For the Euro 5 compliant vehicle:

- The CO emission is lower by $90 \%$,

- The HC emission is lower by $70 \%$,

- The $\mathrm{NO}_{\mathrm{x}}$ emission is four times higher,

- The PM emission is lower by $30 \%$,

- The $\mathrm{CO}_{2}$ emission is higher by $20 \%$,

The on-road emission tests indicate that in relation to some of the exhaust components the emission is several times higher. Hence, a trend is seen to legalize and enforce the on-road exhaust emission measurement in Europe.

\section{Nomenclature/Skróty i oznaczenia}

a acceleration/przyspieszenie

EOBD European On Board Diagnostics/europejski system diagnostyki poktadowej

$\mathrm{E}_{\text {norma }}$ Emission rate obtained in the NEDC test/emisja normatywna

$\mathrm{E}_{\text {rzecz }}$ emission rate obtained under real conditions/emisja rzeczywista w warunkach drogowych

GPS Global Positioning System/system nawigacji satelitarnej

k emission indicators/wskaźnik emisji

NEDC New European Driving Cycle/europejski test jezdny

OBD On-Board Diagnostics/system diagnostyki pokładowej

SUV Sport Utility Vehicle/pojazd sportowo-użytkowy

u share/wspótczynnik udziału

$\mathrm{V} \quad$ vehicle speed/prędkość pojazdu

ZS compression ignition/zapłon samoczynny normy toksyczności oraz wartości emisji związków szkodliwych, uzyskane podczas rzeczywistych warunków ruchu różnią się między sobą. Różnice te w przypadku niektórych związków są znaczne i wynoszą odpowiednio:

- dla pojazdu spełniającego normę Euro 4:

- emisja CO jest mniejsza o $80 \%$,

- emisja $\mathrm{HC}$ jest mniejsza o $80 \%$,

- emisja $\mathrm{NO}_{\mathrm{x}}$ jest większa o $80 \%$,

- emisja PM jest mniejsza o 10\%,

- emisja $\mathrm{CO}_{2}$ jest większa o $10 \%$,

- dla pojazdu spełniającego normę Euro 5:

- emisja CO jest mniejsza o 90\%,

- emisja HC jest mniejsza o 70\%,

- emisja $\mathrm{NO}_{\mathrm{x}}$ jest większa czterokrotnie,

- emisja PM jest mniejsza o 30\%,

- emisja $\mathrm{CO}_{2}$ jest większa o $20 \%$,

Wyniki badań prowadzonych w warunkach rzeczywistych wskazują, że w odniesieniu do niektórych składników toksycznych spalin emisja ta jest większa kilkakrotnie. W związku z powyższym dostrzegalny jest trend usankcjonowania pomiaru emisji związków szkodliwych w warunkach rzeczywistej eksploatacji pojazdów w Europie.

Paper reviewed/Artykut recenzowany

\section{Bibliography/Literatura}

[1] Bougher T., Khalek I.A., Trevitz S., Akard M.: Verification of a Gaseous Portable Emissions Measurement System with a Laboratory System Using the Code of Federal Regulations Part 1065. SAE Technical Paper Series 2010-01-1069.

[2] Jehlik H.: Challenge X 2008 - Hybrid Powered Vehicle OnRoad Emissions Findings and Optimization Techniques: A 4 Year Summary, Sensors 5th Annual SUN (SEMTECH User Network) Conference, 25-26.09.2008.

[3] Johnson T.V.: Review of Diesel Emissions and Control. SAE Technical Paper Series 2010-01-0301.

[4] Merkisz J., Lijewski P., Fuć P., Pielecha J.: Exhaust Emission Tests from Agricultural Machinery under Real Operating Conditions. SAE Technical Paper Series 2010-01-1949.

[5] Merkisz J., Pielecha I., Pielecha J.: Gaseous and PM Emission from Combat Vehicle Engines during Start and Warm-Up. SAE Technical Paper Series 2010-01-2283.

[6] Ochs T., Schittenhelm H., Genssle A., Kamp B.: Particulate Matter Sensor for On Board Diagnostics (OBD) of Diesel Particulate Filters (DPF). SAE Technical Paper 2010-01-0307.

[7] Ortenzi F., Costagliola M.A.: A New Method to Calculate Instantaneous Vehicle Emissions using OBD Data. SAE Technical Paper 2010-01-1289.

Prof. Jerzy Merkisz, DSc., DEng., - Professor in the Faculty of Working Machines and Transportation at Poznan University of Technology.

Prof. Jerzy Merkisz - profesor na Wydziale Maszyn Roboczych i Transportu Politechniki Poznańskiej.

e-mail: jerzy.merkisz@put.poznan.pl
[8] Schwenger C., Wagner U., Spicher U.: Investigation of the Inflow Behavior of a Diesel Particulate Filter Using LaserOptical Measurement Techniques During Soot Loading and Filter Regeneration with the Aim of Improving these Processes. THIESEL Conference on Thermo- and Fluid Dynamic Processes in Diesel Engines, Valencia 2010.

[9] Seger J.P.: Vehicle Integration for US EPA 2010 Emissions and Lowest Cost of Ownership. SAE Technical Paper 201001-1956.

[10] Steininger N.: Automotive particulate emissions in European legislation: state of the art and developments to come. 13th ETH Conference on Combustion Generated Particles, Zurich 2009.

[11] Wei Q., Rooney R.: The On-Board PM Mass Calibration for the Real-Time PM Mass Measurement. SAE Technical Paper 2010-01-1283.

[12] Yu Jinghong, Hosni E., Haskell J.: Application of Fuel and Cost Efficient Steering Technology - Variable Displacement Pump - to SUV/SUTS. World Automotive Congress Fisita, F2010-A-032, Budapest 2010.

Jacek Pielecha, DEng. - Doctor in the Faculty of Working Machines and Transportation at Poznan University of Technology.

Dr inż. Jacek Pielecha - adiunkt na Wydziale Maszyn Roboczych i Transportu Politechniki Poznańskiej.

e-mail: jacek.pielecha@put.poznan.pl

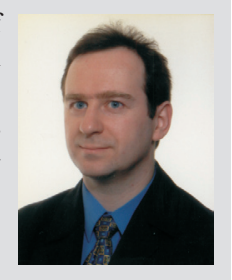

